\title{
A simplified 3D liver microsphere tissue culture model for hepatic cell signaling and drug-induced hepatotoxicity studies
}

\author{
YING ZHU $^{1 *}$, QIONG SHI ${ }^{1 *}$, QI PENG ${ }^{1}$, YUE GAO $^{1}$, TING YANG $^{1}, \mathrm{YU} \mathrm{CHENG}^{1}, \mathrm{HAO} \mathrm{WANG}^{1}$, \\ YETAO LUO ${ }^{2}$, AILONG HUANG ${ }^{3}$, TONG-CHUAN HE ${ }^{4}$ and JIAMING FAN ${ }^{1}$ \\ ${ }^{1}$ Ministry of Education Key Laboratory of Diagnostic Medicine, School of Laboratory Medicine and \\ ${ }^{2}$ Department of Biostatistics, School of Public Health and Management, Chongqing Medical University, Chongqing 400016; \\ ${ }^{3}$ Key Laboratory of Molecular Biology for Infectious Diseases of The Ministry of Education of China, \\ Institute for Viral Hepatitis, Department of Infectious Diseases, The Second Affiliated Hospital of \\ Chongqing Medical University, Chongqing 400037, P.R. China; ${ }^{4}$ Molecular Oncology Laboratory, Department of \\ Orthopedic Surgery and Rehabilitation Medicine, The University of Chicago Medical Center, Chicago, IL 60637, USA
}

Received March 16, 2019; Accepted July 25, 2019

DOI: $10.3892 / \mathrm{ijmm} .2019 .4321$

\begin{abstract}
Although a number of experimental models have been developed for liver research, each has its own advantages and disadvantages. The present study attempted to develop a simple and effective 3-dimensional mouse liver microsphere tissue culture (LMTC) model in vitro for the analysis of hepatic functions. Hepatic characteristics and potential applications of this model were compared with that of mouse model in vivo and mouse primary hepatocytes in vitro. Using freshly-perfused mouse liver tissue passed through 80-mesh sift strainer (sift80), it was demonstrated that under the optimal culture conditions, the sift80 microsphere tissue cultured in $2 \%$ bovine calf serum medium remained viable with marked proliferating cell nuclear antigen and anti-Myc proto-oncogene protein expression, exhibited normal hepatic functions including indocyanine green (ICG) uptake/release and periodic acid-Schiff staining, and expressed hepatocyte-specific genes for up to 2 weeks. The microsphere tissue was responsive to bone morphogenic protein 9 (BMP9) stimulation leading to upregulation of downstream targets of BMP9 signaling. Furthermore, 3 commonly-used liver-damaging drugs were indicated to effectively inhibit hepatic ICG uptake, and induce the expression of hepatotoxicity-associated genes. Therefore, this simplified LMTC model may be a useful in vitro tissue
\end{abstract}

Correspondence to: Dr Jiaming Fan, Ministry of Education Key Laboratory of Diagnostic Medicine, School of Laboratory Medicine, Chongqing Medical University, 1 Medical College Road, Yuzhong, Chongqing 400016, P.R. China

E-mail: fanjiaming1988@cqmu.edu.cn

*Contributed equally

Key words: primary liver tissue culture, exogenous investigation, hepatotoxicity prediction culture model to investigate drug-induced liver injury and metabolism, and hepatocyte-based cell singling.

\section{Introduction}

The liver serves a complex and vital role in metabolism, synthesis, storage and redistribution of nutrients, carbohydrates, fats and vitamins in the body (1-3). It is one of the few organs that has retained a high regenerative potential, allowing the recovery of $>50 \%$ of its total mass following damage or loss excretion $(1,2,4,5)$. The functional units of the liver are organized into lobules, which are subsequently organized into larger lobes (1). Lobules consist of multiple hepatic sinusoids, where the flow of blood from the portal triad to the central vein contributes to a zonation based on decreasing oxygen tension, which affects both the parenchymal (hepatocytes) and non-parenchymal cells (NPCs) (1). The hepatocytes account for $60 \%$ of the cell population and are responsible for the biological functions of the liver, while the NPCs comprise the remaining $40 \%$ of the cell population and serve an important role in maintaining tissue architecture, mediating responses to metabolic and toxic stimuli, and in supporting hepatocyte functions (1). NPCs contain multiple cell types, including liver sinusoidal endothelial cells, Kupffer cells, hepatic stellate cells, and pit cells (natural killer cells) (1). Given the vital roles of the liver, severe liver damage under pathological conditions may lead to high morbidity and mortality, and liver diseases represent a growing global health burden.

The liver is also the major organ responsible for detoxifying drugs, chemical wastes and xenobiotics through biotransformation $(1,2,4,5)$. As a result, the liver is the most important target for drug-induced toxicity (6). Drug-induced liver injury (DILI) is a significant leading cause of acute, chronic liver disease and an important safety issue when developing new drugs (1,3,6-11). For example, in the United States of America $\sim 2,000$ cases of acute liver failure occur annually; DILI accounts for $>50 \%$ of these, among which $37 \%$ are caused by acetaminophen and $13 \%$ are idiosyncratic reactions caused 
by other medications (11). Furthermore, DILI accounts for $2-5 \%$ of the patients hospitalized with jaundice and $\sim 10 \%$ of all cases of acute hepatitis (11). Therefore, it is essential to develop valid models to assess and/or predict drug hepatotoxicity.

In previous decades, numerous in vitro and in vivo models have been developed to assess drug-induced hepatotoxicity, particularly for novel drug development $(1,3,6-10,12)$. In vivo animal models have been used to assess hepatotoxicity, although such models are usually expensive and time-consuming. Furthermore, animal models are not always good predictors of human-relevant DILI, owing to significant species-specific differences in drug metabolism pathways $(3,13,14)$, although big data approaches may improve the concordance of the toxicity of pharmaceuticals in animals and humans (15). Conversely, the majority of in vitro assay models involve the use of primary hepatocytes, established liver cell lines, liver slices, microsomes, perifusion culture systems, co-culture systems, bioreactors, liver 'organ-on-chip', and/or liver organoids, each of which has its own advantages and disadvantages (1,3,6-10,12,14,16-24). An ideal in vitro hepatic function assessment model should retain the normal architecture of hepatocytes and NPCs, and be easy to construct. $(1,3,6-10,12,14,16-24)$.

The present study aimed to establish a highly simplified yet effective 3-dimensional (3D) mouse liver microsphere tissue culture (LMTC) model to assess hepatic functions that may be impaired by hepatotoxins through a comparison of primary hepatocytes and a mouse model. By freshly preparing perfused mouse liver tissue with 80 -mesh sift strainer, it was demonstrated that the liver microsphere tissue exhibited normal hepatic functions for up to 2 weeks and exhibited normal hepatic functions; however, apparent tissue degradation and debris release, along with diminished hepatic functions, were observed in the 2-week microsphere culture. It was also demonstrated that the microsphere tissue was responsive to bone morphogenic protein 9 (BMP9) stimulation with the upregulation of numerous downstream target genes of BMP9 signaling. Furthermore, it was revealed that 3 commonly used drugs, levofloxacin, azithromycin and paracetamol, effectively inhibited hepatic indocyanine green (ICG) uptake and induced higher expression levels of hepatotoxicity-associated genes compared with that of the animals treated with these drugs in vivo, suggesting that the LMTC model may be more sensitive in detecting and predicting drug-associated hepatotoxicity. Therefore, the simplified LMTC model should be useful for drug hepatotoxicity and hepatocyte-based singling studies.

\section{Materials and methods}

Cell culture and chemicals. Mouse primary hepatocytes (MPH) were obtained from 4-week-old C57 mice using a previously described type I collagenase liver perfusion protocol (19,25-30). 293-Derived 293pTP cells were previously described $(25,31)$. The human colon cancer HCT116 cell line were obtained from the American Type Culture Collection. The cells were maintained in complete Dulbecco's modified Eagle's medium (DMEM) supplemented with 10\% FBS (Lonsa Science SRL), $100 \mathrm{U}$ penicillin and $100 \mu \mathrm{g}$ streptomycin at $37^{\circ} \mathrm{C}$ in $5 \% \mathrm{CO}_{2}$. Levofloxacin, azithromycin and paracetamol were purchased from Sigma-Aldrich; Merck KGaA. Unless indicated otherwise, all other reagents were purchased from Thermo Fisher Scientific, Inc. or Sigma-Aldrich; Merck KGaA.

Mouse perfusion and liver tissue recovery, and the establishment of mouse LMTC model. The use and care of animals in the present study was approved by the Research and Experimental Animal Use Ethics Committee of Chongqing Medical University (Chongqing, China; permit no. SCXK(YU)20070001). All animal experiments were performed in accordance with US National Institutes of Health Guide for the Care and Use of Laboratory Animals (32). The 4-week-old C57BL/6 male mice were obtained from the Animal Resource Center of Chongqing Medical University.

Anesthesia was performed using intraperitoneal injection of $3 \%$ sodium pentobarbital at a dose of $50 \mathrm{mg} / \mathrm{kg}$. Harvesting of mouse liver tissue was performed according to a modified liver perfusion protocol (33-37). Specifically, following anesthesia of the mice, following aseptic techniques, an incision was made in upper-middle abdomen across the abdominal and chest cavities to expose the liver and heart. Following the blockade of the right heart circulation, perfusion of $\sim 15 \mathrm{ml}$ cold sterile PBS was rapidly performed from the left ventricular until the liver turned pale. Concomitantly, the rapid intra-cardiac perfusion led to acute cardiac arrest and mortality of the mice, which was additionally confirmed by cervical dislocation. Mice in the control non-perfusion group were sacrificed with $\mathrm{CO}_{2}$, followed by cervical dislocation.

The liver was resected and rinsed in PBS twice in 10-cm cell culture dishes, and then cut into small tissue pieces with ophthalmic scissors, followed by passing the minced liver tissue through 80-mesh (sift80) or 200-mesh (sift200) cell strainer/filter. The recovered microsphere tissue pieces were washed with sterile PBS by low speed centrifugation [500 x g for $5 \mathrm{~min}$ at room temperature (RT)], and immediately used for the in vitro culture assays as described subsequently.

To establish the LMTC model, the recovered liver microsphere tissue pieces were cultured in 24-well plates with various concentrations of FBS and/or bovine calf serum (BCS; Sijiqing; Zhejiang Tianhang Biotechnology Co., Ltd.) containing $100 \mathrm{U}$ penicillin and $100 \mu \mathrm{g}$ streptomycin at $37^{\circ} \mathrm{C}$ in $5 \% \mathrm{CO}_{2}$. Medium was changed daily for the first 3 days, and then changed every other day.

Amplification and titering of recombinant adenoviruses expressing BMP9 or green fluorescent protein (GFP). Recombinant adenoviruses were generated by using the AdEasy technology and amplification as described previously (38-40). The Recombinant adenovirus Ad-BMP9 was previously characterized (41-45). Ad-BMP9 also co-expresses enhanced GFP. An analogous adenovirus expressing GFP (Ad-GFP) was used as a mock virus control. For all adenoviral infections, polybrene $(4-8 \mu \mathrm{g} / \mathrm{ml})$ was added to potentiate infection efficiency as described previously (46).

Preparation of BMP9-conditioned medium from HCT116 cells. The preparations for BMP9 conditioned medium were performed as previously described (45). Briefly, subconfluent HCT116 cells were infected with the optimal titer (MOI =50) of Ad-BMP9. At $24 \mathrm{~h}$ after infection, the culture was changed to serum-free Opti-MEM media (Thermo Fisher Scientific, Inc.). 
The media were collected every $12 \mathrm{~h}$ for 4 times consecutively. The pooled BMP9 conditioned medium was centrifuged at $500 \mathrm{x} \mathrm{g}$ for $10 \mathrm{~min}$ at RT to remove any cell debris, aliquoted and stored at $-80^{\circ} \mathrm{C}$. The control conditioned medium was also prepared in the same fashion from Ad-GFP infected HCT116 cells $(45,47)$.

Hematoxylin and eosin (H\&E) staining and Hoechst33258 staining. The recovered liver tissue was rinsed with PBS, fixed with $4 \%$ paraformaldehyde for $30 \mathrm{~min}$ at RT, and subjected to $H \& E$ staining as described previously (48-50). The fixed tissue was also stained with Hoechst33258 $(10 \mu \mathrm{g} / \mathrm{ml}$ Hoechst 33258 in PBS) for $5 \mathrm{~min}$ at RT, examined and recorded under a fluorescence microscope (magnification, $\mathrm{x} 200$ ).

Immunohistochemical (IHC) and immunofluorescence (IF) staining on liver microsphere tissue. The IHC and IF staining of the liver microsphere tissue were performed as described previously (51-53). The recovered liver tissue was fixed with $4 \%$ paraformaldehyde for $30 \mathrm{~min}$ at $\mathrm{RT}$, followed by antigen retrieval and immunostaining with anti-proliferating cell nuclear antigen (PCNA; 1:100-1:200; cat. no. 13110; Cell Signaling Technology, Inc.) or anti-Myc proto-oncogene protein (c-Myc; 1:100-1:200; cat. no. ab39688; Abcam) antibodies. Control rabbit IgG (1:200; cat. no. 011-000-003; Jackson ImmunoResearch Laboratories, Inc.) was used as a negative control.

ICG uptake/release assay. The ICG uptake/release assay was performed as described previously (30). Briefly, recovered liver tissue and cells were washed with PBS and incubated with ICG $\left(1 \mathrm{mg} / \mathrm{ml}\right.$ in complete DMEM) at $37^{\circ} \mathrm{C}$ for $30 \mathrm{~min}$, followed by two washes with PBS. For ICG release detection, the ICG-containing medium was replaced with $2 \% \mathrm{BCS}$ DMEM, and the tissue and cells were incubated for an additional $3 \mathrm{~h}$ at $37^{\circ} \mathrm{C}$ in a cell culture incubator. ICG uptake/release was observed and recorded under a bright field microscope (magnification, x200).

Periodic acid-Schiff (PAS) staining. PAS staining was performed as described previously $(19,27,28,30)$. Briefly, recovered liver tissue was fixed with $4 \%$ paraformaldehyde for $30 \mathrm{~min}$ at RT, followed by staining with $0.5 \%$ periodic acid solution for $5 \mathrm{~min}$ at RT. Following rinsing in distilled water for $3 \mathrm{~min}$, the tissues were incubated in the Schiff's reagent for $15 \mathrm{~min}$, followed by thorough rinsing with tap water. Cell staining was recorded under a bright field microscope (magnification, $\mathrm{x} 200)$.

Total RNA isolation and touchdown reverse transcriptionquantitative polymerase chain reaction (TqPCR) analysis. Total RNA from both tissue and cells was isolated by using TRIzol reagent (CoWin Biosciences) according to the manufacturer's protocol. The perfused mouse liver tissues from normal 6-week-old C57BL/6 mice ( $\mathrm{n}=5$ males/group) and drug or PBS-treated 6-week-old C57BL/6 mice ( $\mathrm{n}=5$ males/group) were dissected out and homogenized in the TRIzol reagent. The recovered liver tissue and cells were lysed in TRIzol reagent. Total RNA was extracted and subjected to reverse transcription reactions with hexamer and $\mathrm{M}-\mathrm{MuLV}$ reverse transcriptase (New England Biolabs, Inc.). The cDNA products were additionally diluted and used as PCR templates. The gene-specific PCR primers (Table SI) were designed using Primer3 Plus (http://www.bioinformatics.nl/cgi-bin/primer3plus/primer3plus.cgi). TqPCR was performed using SYBR Green-based TqPCR analysis on a CFX-Connectunit system (Bio-Rad Laboratories, Inc.), as described previously (54). TqPCR reactions were performed in triplicate. GAPDH was used as the reference gene. Quantification of gene expression was performed using the $2^{-\Delta \Delta \mathrm{Cq}}$ method (55).

WST-1 cell proliferation assay. Cell proliferation was assessed using the Premix WST-1 Cell Proliferation Assay System (Clontech Laboratories, Inc.), as described previously (56-59). The MPH seeded in 96-well plates at 6,000 cells/well were treated with levofloxacin (at 1,5 and $25 \mu \mathrm{M}$ ), azithromycin (at 25, 125 and $625 \mathrm{nM}$ ), paracetamol (at 20, 100 and $500 \mu \mathrm{M}$ ) or DMSO for 24, 48 or $72 \mathrm{~h}$. The Premix WST-1 Reagent was added to each well, followed by incubation at $37^{\circ} \mathrm{C}$ for $60 \mathrm{~min}$ and reading at $440 \mathrm{~nm}$ using the EL800 microplate reader (BioTek Instruments, Inc.). Each assay was performed in triplicate.

Statistical analysis. All quantitative experiments were performed in triplicate and/or repeated 3 times. Data are presented as mean \pm standard deviation. Significant differences between groups were determined using a one-way analysis of variance followed by a Least Significant Difference post hoc test. $\mathrm{P}<0.05$ was considered to indicate a statistically significant difference.

\section{Results}

Optimization of the culturing conditions for the $3 D$ LMTC model using mouse liver tissue. Liver tissue is rich in blood cells and lipofuscin, pyridine (NADPH) and flavin coenzymes, which are common causes of high auto-fluorescence. To minimize the cytotoxicity and auto-fluorescence caused by blood cell disintegration, left ventricular perfusion was performed to remove intrahepatic blood in the anesthetized mice (Fig. 1A-a). The liver tissue was prepared in different sizes by sifting through sift 80 or sift 200 filter strainers, and the microsphere tissue preparations were cultured in different concentrations of FBS or BCS-containing DMEM (Fig. 1A-b). The perfused liver tissue culture exhibited significantly decreased auto-fluorescence at 24 and $72 \mathrm{~h}$ after culturing, compared with culture established with tissue from the non-perfusion group (Fig. 1A-c).

When the liver microsphere tissue sifted with the sift 80 strainer was cultured with 0,2 or $10 \%$ FBS or BCS DMEM medium, followed by medium change every day for the first 3 days, and then every other day for the rest of the study period, it was identified that the microsphere tissue was in the healthiest state in $2 \%$ BCS medium (Fig. 1B-a).

It was also identified that non-sifted liver tissue pieces were mostly suspended in $2 \%$ BCS medium, and the sift 80 tissue was mostly attached to the bottom of the culture plates and grew healthily for up to 14 days in $2 \%$ BCS medium (Fig. 1B-b). Notably, the sift200 microsphere tissue was demonstrated to grow somewhere in between that of the non-sifted tissue and 
sift 80 microsphere tissue at day 7 , but significantly deteriorated at day 14 (Fig. 1B-b). It is noteworthy that, although the LMTC culture could be passaged 1 to 2 times, the percentage of viable cells that survived the passages was rather low, at $<10 \%$ (data not shown). Collectively, these results indicated that the optimal LMTC culturing conditions should include preparation of the mouse liver tissue with 80-mesh sift strainer and culturing of the sift 80 microsphere tissue in $2 \%$ BCS/DMEM medium with daily medium change for the first $72 \mathrm{~h}$, and then once every 2 days thereafter.

Proliferative and apoptotic characteristics of the 3DLMTC model. The long-term survival of the LMTC model was additionally analyzed by culturing sift 80 microspheres in $2 \%$ BCS/DMEM for up to 14 days. H\&E staining of the sift 80 microsphere tissue in $2 \% \mathrm{BCS} / \mathrm{DMEM}$ was performed and it was identified that the cellularity was preserved at the 3 timepoints examined (days 3, 7 and 14), although the microsphere tissue scaffolds became loose and disintegrated to a certain extent (Fig. 2A-a). Accordingly, the Hoechst 33258 staining assay indicated that the majority of the cell nuclei were readily visible without any apparent fragmentation (Fig. 2A-b).

It was also identified that the sift 80 microsphere tissue exhibited strong positive staining for PCNA at days 3 and 7, with a decreased level of staining at day 14 (Fig. 2A-c, top row). Similarly, high levels of c-Myc expression were observed at days 3 and 7, although the levels had significantly decreased by day 14 (Fig. 2A-c, bottom row). These IHC staining results were further confirmed by IF staining. As liver tissue exhibits auto-fluorescence, Sudan Black B was employed to effectively suppress background fluorescence (Fig. 2B-a). IF staining with PCNA and c-Myc antibodies indicated that the sift 80 microspheres markedly expressed both PCNA and c-Myc at day 7, but that the levels were rather weak at day 14. Taken together, these results demonstrate that the sift 80 microspheres may be healthily maintained for at least 7 days, and potentially for up to 14 days.

Hepatic functional characteristics of the 3D LMTC model. To determine whether the cultured microsphere tissue exhibited normal liver functions, ICG uptake/release and Periodic Acid-Schiff (PAS) staining of glycogen storage assays were performed, which are liver-specific functions $(19,28,60)$. It was identified that the sift 80 microsphere tissue cultured at days 3 and 7, and to a lesser extent at day 14, was able to uptake ICG effectively (Fig. 3A-a). Conversely, it was demonstrated that the ICG was effectively released from the cultured sift 80 microsphere tissue at the 3 time points examined (Fig. 3A-b). Furthermore, marked PAS staining of the cultured sift 80 microsphere tissues indicated that the hepatocytes were viable and healthy, particularly at days 3 and 7 (Fig. 3B). These results suggested that the sift 80 microsphere tissue may retain normal hepatic functions under the in vitro culture conditions for up to 14 days.

To additionally determine whether the in vitro culture would affect hepatic gene expression pattern, the expression profiles of a panel of eight hepatocyte-specific genes were compared $(19,27,28,30,61-63)$ in the cultured microspheres and that of the freshly-isolated mouse liver tissue and the MPH. Using TqPCR analysis, it was identified that cytochrome P450 family 1 subfamily Amember 2, cytochrome P450 family 3 subfamily Amember 4, microsomal glutathione S-transferase 1 and albumin (Alb), and to a lesser extent cytochrome P450 2A5 and $M a o b$, were highly expressed in the sift 80 microsphere tissue cultured at days 3, 7 and 14, and in the freshly-prepared mouse liver tissue and in the MPH, although their expression in the sift 80 microsphere tissue samples decreased over time (Fig. 3C). Conversely, the expression levels of $\alpha$ fetoprotein and MET proto-oncogene, receptor tyrosine kinase were low or undetectable in all samples (Fig. 3C). The hepatic gene expression in the microsphere tissue samples appeared to decrease over time, particularly at day 14 , which may be indicative of lower viability of the microsphere tissue after culture for 2 weeks. Collectively, these results demonstrated that the LMTC samples exhibited a normal hepatic gene expression profile under the in vitro culture conditions for at least 7 days, and potentially up to 14 days, although the 2-week microsphere culture exhibited apparent morphological changes with signs of tissue degradation and tissue debris (data not shown). Therefore, considering the morphological changes and the diminished hepatic functions and gene expression profile of the 2-week microsphere culture, the LMTC microspheres' viability may be limited to no longer than 2 weeks under the culture conditions of the present study.

3D LMTC model for hepatocyte-based cell signaling investigation. Whether the LMTC model could be used to study the cell-based signaling pathways that may be involved in the effective delivery of transgenes into the microsphere tissue or exposure to secreted growth factors was examined. Whether the mouse liver microsphere tissue could be effectively transduced with recombinant adenoviruses, which represent one of the most effective gene delivery approaches, was first investigated. Considering the fact that the liver tissue may exhibit different proliferative potential at different ages, sift 80 microsphere tissues from newborn, 14-day-old and 28-day-old mouse liver tissue were prepared, and then infected with the same titer of adenovirus Ad-GFP. Only sparsely infected $\mathrm{GFP}^{+}$hepatocytes were detected in the sift 80 microsphere tissue prepared from newborn mice at days 3 and 7, while $\mathrm{GFP}^{+}$cells were very few or undetectable in the microsphere tissue from 14-day-old and 28-day-old mouse liver tissue; the Ad-GFP-infected MPH cells were used for the control (Fig. 4A). In fact, the adenovirus-mediated transgene delivery to whole mouse liver tissue was analyzed in vitro at $0,3,7,10$ and 14 days after birth, and only sparsely distributed, focal Ad-GFP infection was observed (data not shown). These results suggest that mouse liver tissues, whilst viable in culture, may have limited intrinsic proliferative potential for transgene expression in vitro.

Whether liver microsphere tissues were responsive to signal molecule stimulation was then examined. It has been previously demonstrated that BMP9 is a highly expressed secreted protein in fetal mouse liver tissues, and that it exerts pleiotropic effects on stem cell proliferation and differentiation (41-43,64-68). The BMP9-containing conditioned medium was first prepared by infecting HCT116 cells with Ad-BMP9, as described previously $(45,47,69)$, while the Ad-GFP-infected HCT116 cells were used to prepare for the control conditioned medium (Fig. S1). A high level of BMP9 
A

a

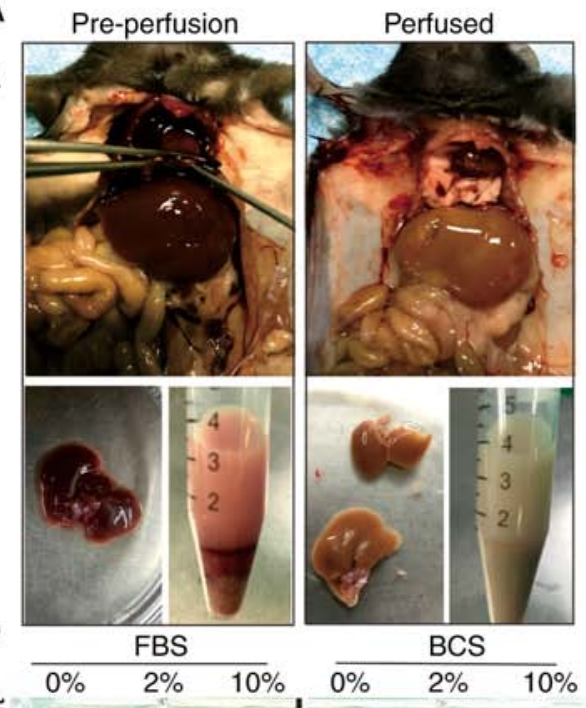

b

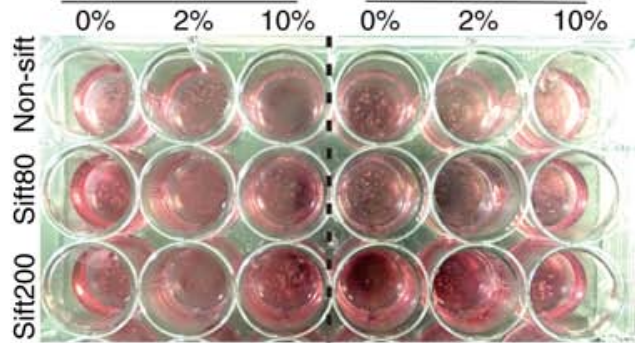

C

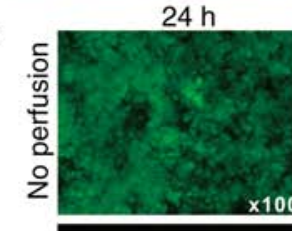

$72 \mathrm{~h}$

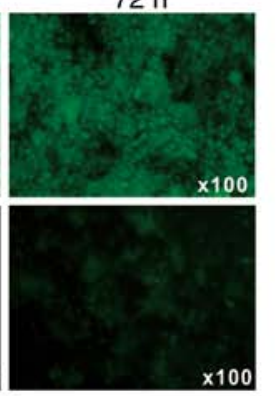

$\mathrm{B}$
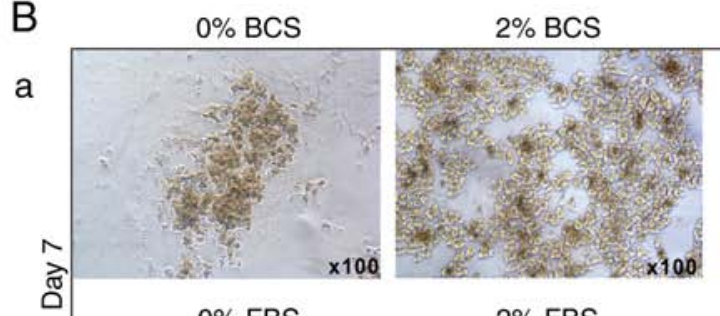

$2 \%$ FBS
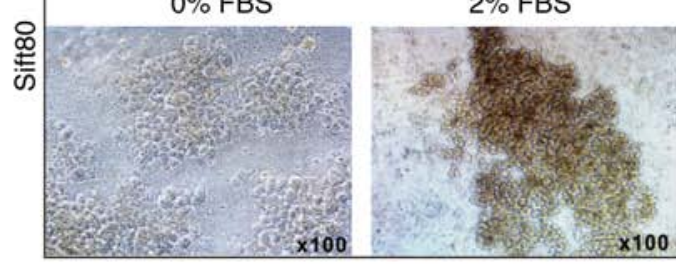

b $2 \%$ BCS

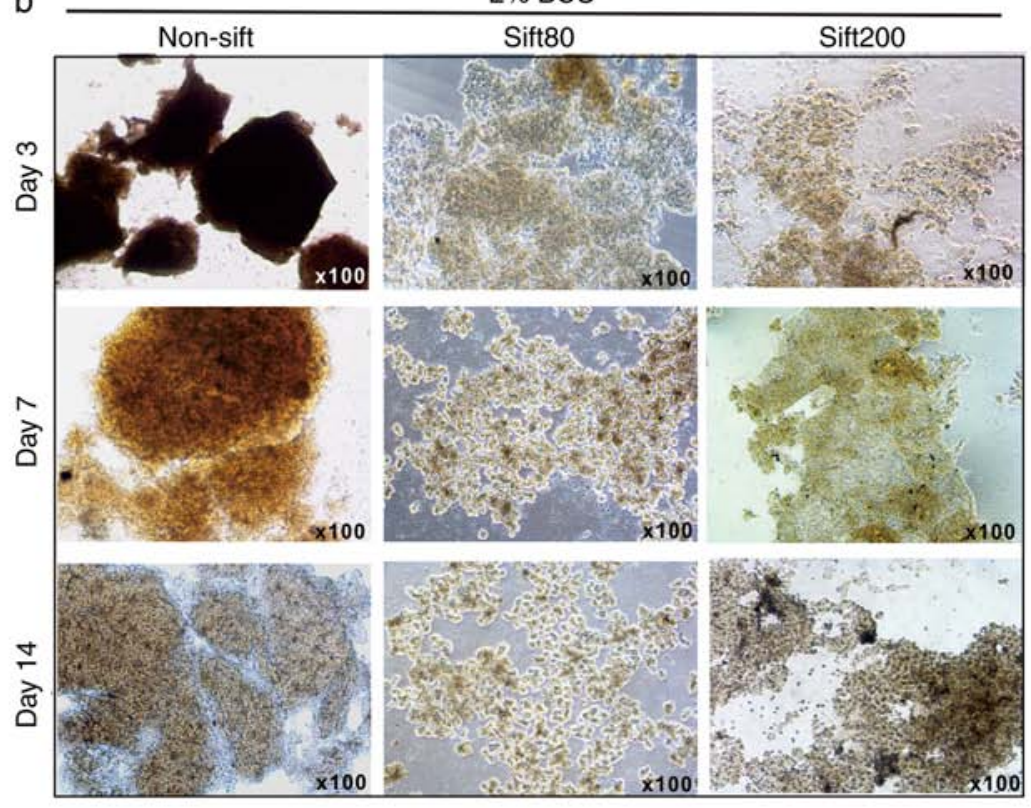

Figure 1. Establishment of the 3-dimensional mouse liver microsphere tissue culture model. (A-a) Liver perfusion and isolation of mouse liver tissue. (b) Liver tissue was resected and rinsed with sterile PBS, followed by low speed centrifugation to remove blood cells. The recovered liver tissue was additionally minced and passed through 80-mesh (sift80) or 200-mesh (sift200) sift/strainers, and cultured in different concentrations of FBS or BCS/DMEM medium. (c) The recovered microsphere tissue exhibited significant auto-fluorescence, which was decreased by perfusion. (B-a) The morphology of the sift 80 microsphere tissue cultured in 0,2 or $10 \%$ FBS or BCS/DMEM at 7 days post-recovery, and (b) various sizes of liver tissue cultured in $2 \%$ BCS/DMEM at 0,7 and 14 days after recovery. Each assay condition was performed in triplicate. Representative images are presented. BCS, bovine calf serum; DMEM, Dulbecco's modified Eagle's medium.

expression in the Ad-BMP9-infected HCT116, but not in the Ad-GFP infected cells, was confirmed by qPCR (Fig. S1). The BMP9-conditioned medium and GFP control medium were used to stimulate the freshly prepared sift 80 microsphere tissue (Fig. 4B). At 3, 7 and 14 days post-BMP9 stimulation, total RNA was isolated and TqPCR analysis of BMP9 downstream target genes was performed as described previously (65,70-73). It was identified that the BMP9 downstream early responsive genes, Smad6 and $S m a d 7$, were significantly upregulated at day 3, while other target genes including inhibitor of DNA binding 1, HLH protein, inhibitor of DNA binding 2, connective tissue growth factor and cellular communication network factor 1 were significantly upregulated at days 3 and 7. However, the expression of the majority of the target genes significantly decreased to basal level at day 14 of culturing. Taken together, these results suggested that mouse liver microsphere tissues, whilst not serving as an ideal recipient for transgene delivery, may be used as an effective in vitro 3D model system for cytokine or growth factor-based cell signaling studies.

3D LMTC model for drug-induced hepatotoxicity assays. As DILI remained the leading cause of acute liver failure and post-market drug withdrawals (5), whether the liver microspheres could be used to assess the hepatotoxicity induced by liver injury drugs was assessed. A total of 3 commonly-used hepatotoxic drugs, levofloxacin, azithromycin and paracetamol, were selected. Using a WST-1 cell proliferation assay, it was identified that the 3 drugs inhibited cell proliferation rates of the MPH in a dose- and time-dependent manner (Fig. 5A). Therefore, the following optimal doses were selected for subsequent in vitro studies: Levofloxacin at $5 \mu \mathrm{M}$ (Fig. 5A-a), 
A
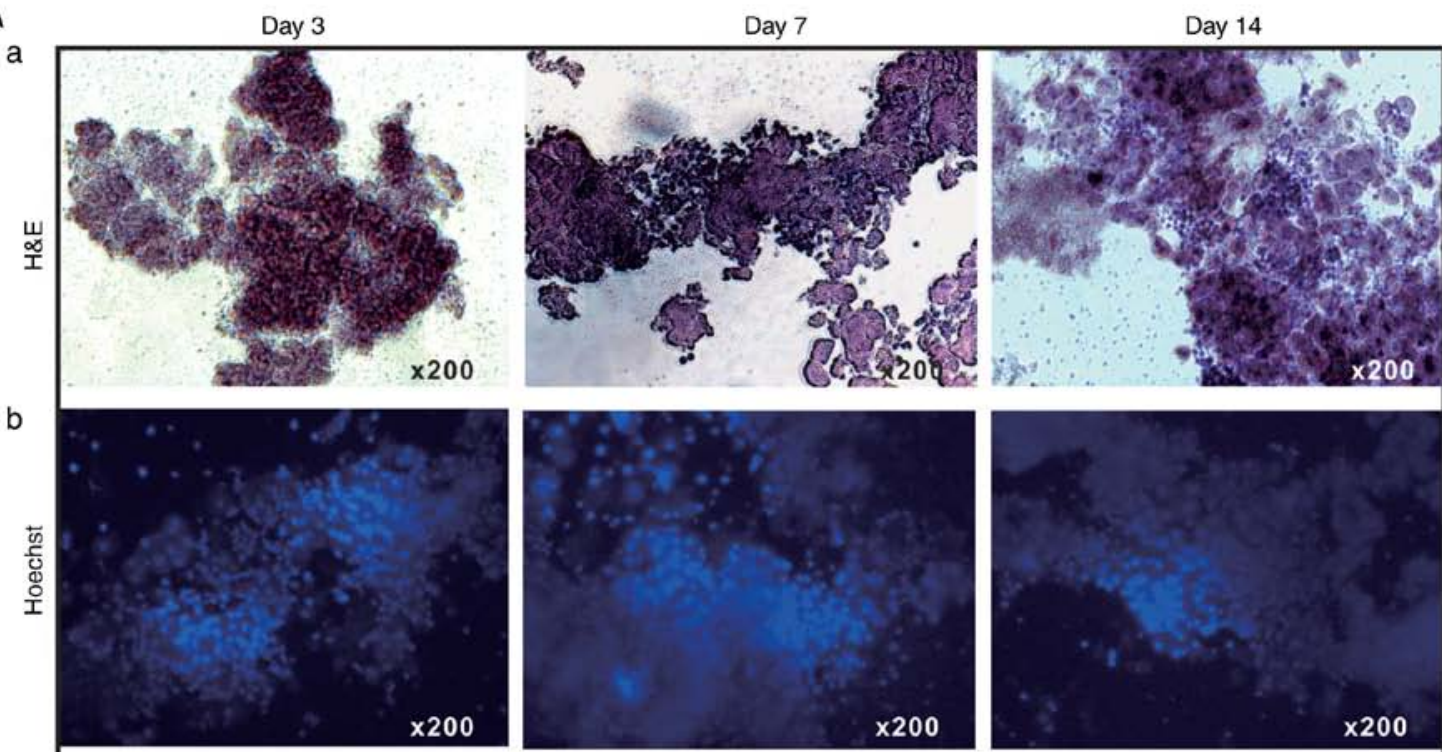

c
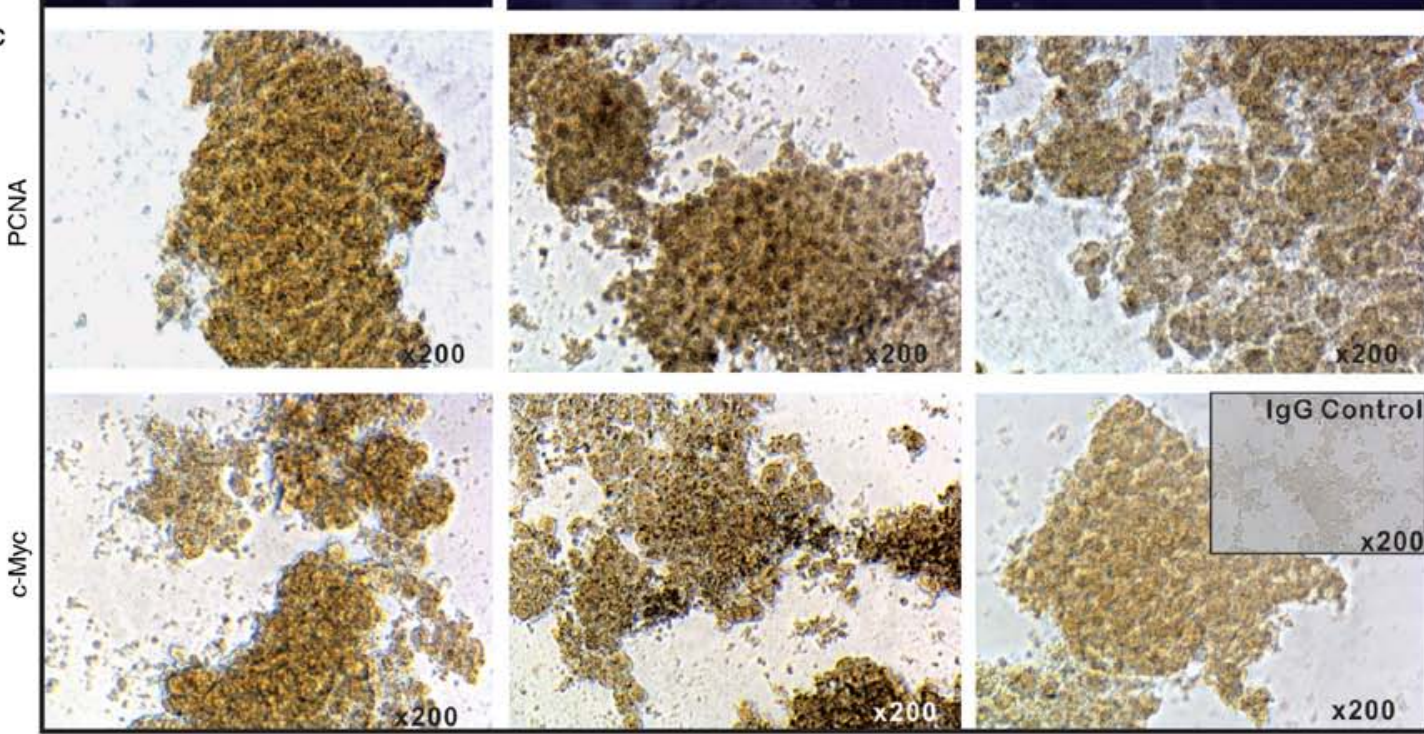

B

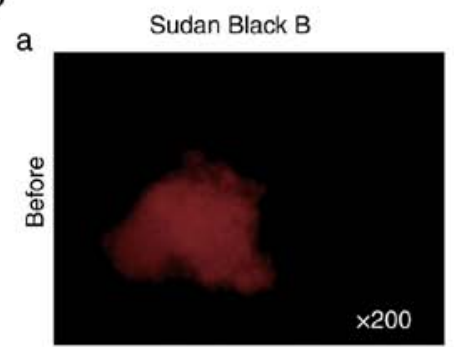

b
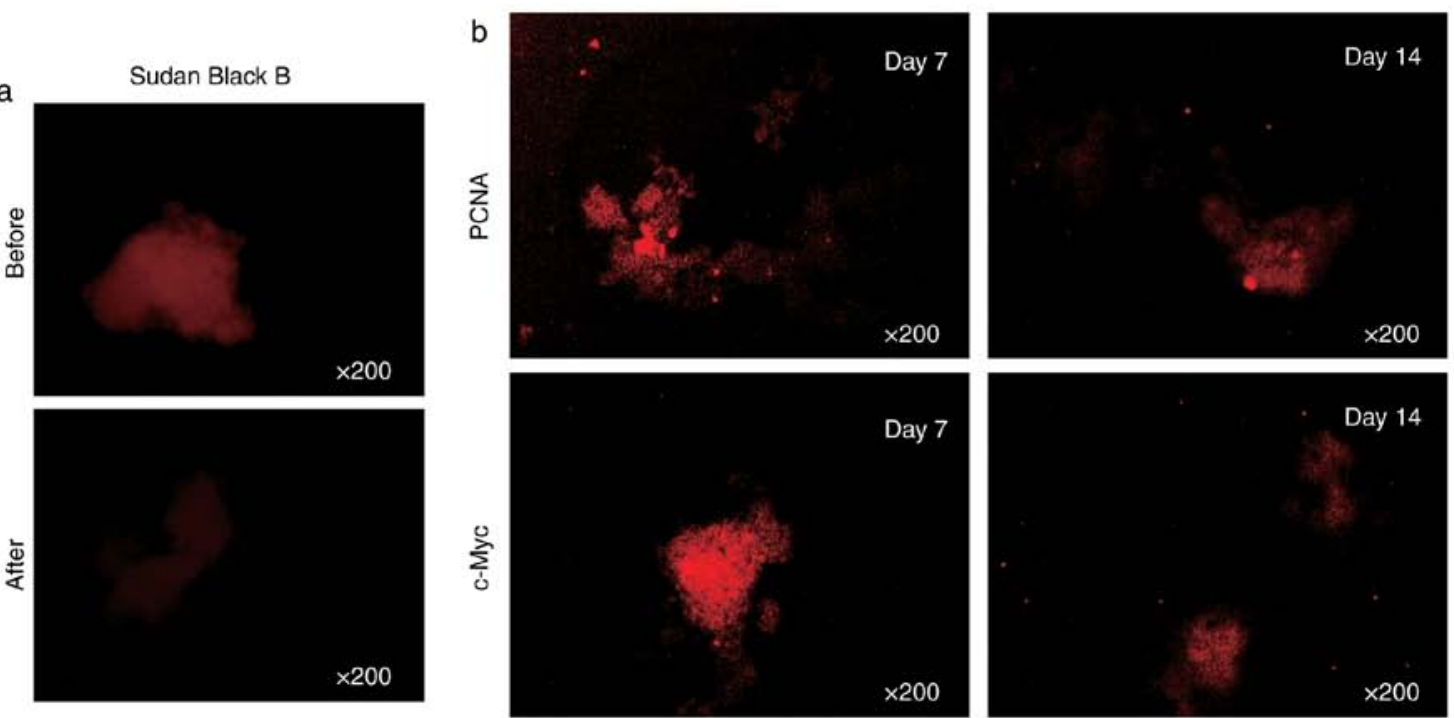

Figure 2. Proliferation and apoptosis features of the 3-dimensional liver microsphere tissue culture model. (A-a) The freshly recovered mouse liver sift 80 microsphere tissue was cultured in 2\% BCS/DMEM for 3, 7 and 14 days, and were then subjected to (a) H\&E staining, (b) Hoechst 33258 staining and (c) immunohistochemical staining for PCNA or c-Myc. (B) IF staining for PCNA or c-Myc. (a) Sudan Black B (5\%) treatment was used to significantly decrease auto-fluorescence. (b) The cultured sift 80 microsphere tissue were subjected to IF staining for either PCNA or c-Myc at the indicated time points, followed by blocking with 5\% Sudan Black B to eliminate background fluorescence. Control IgG was used as a negative control. Each assay condition was performed in triplicate. Representative results are presented. H\&E, hematoxylin and eosin; DMEM, Dulbecco's modified Eagle's medium; PCNA, proliferating cell nuclear antigen; c-Myc, anti-Myc proto-oncogene protein; IF, immunofluorescence. 
A
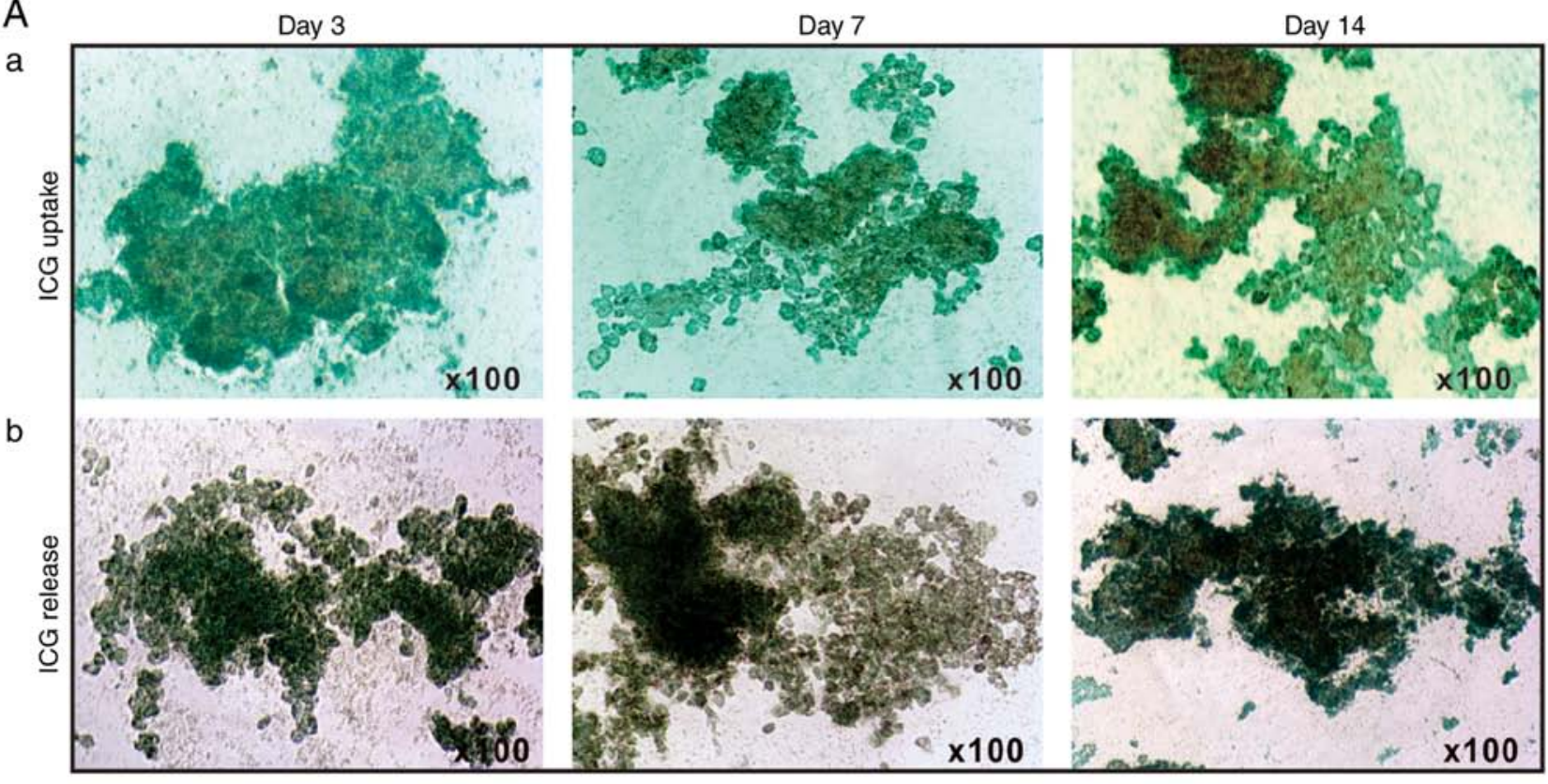

B
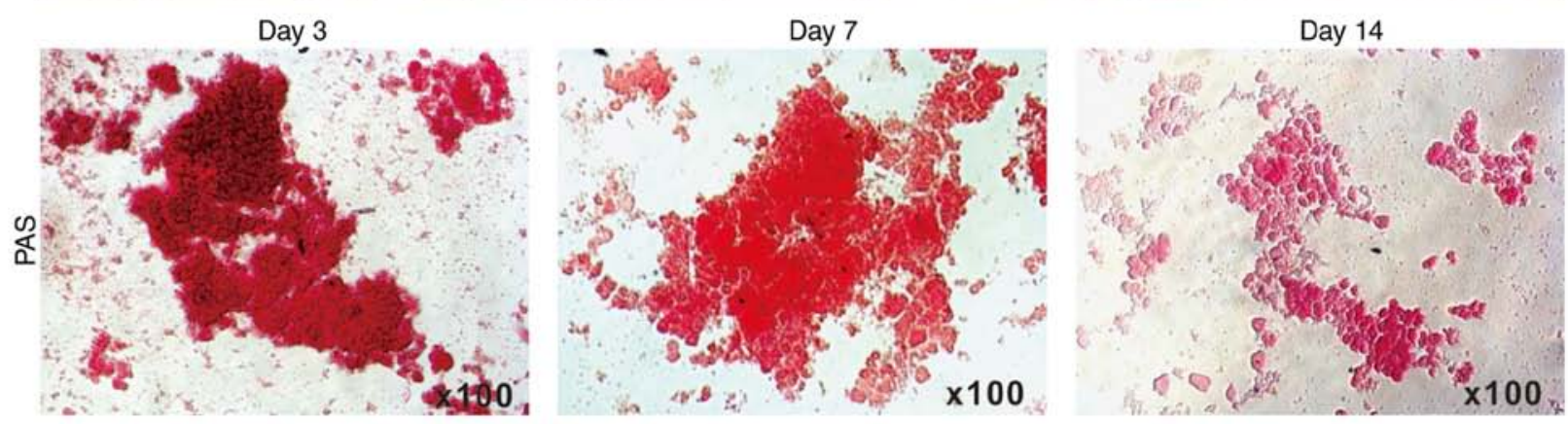

C

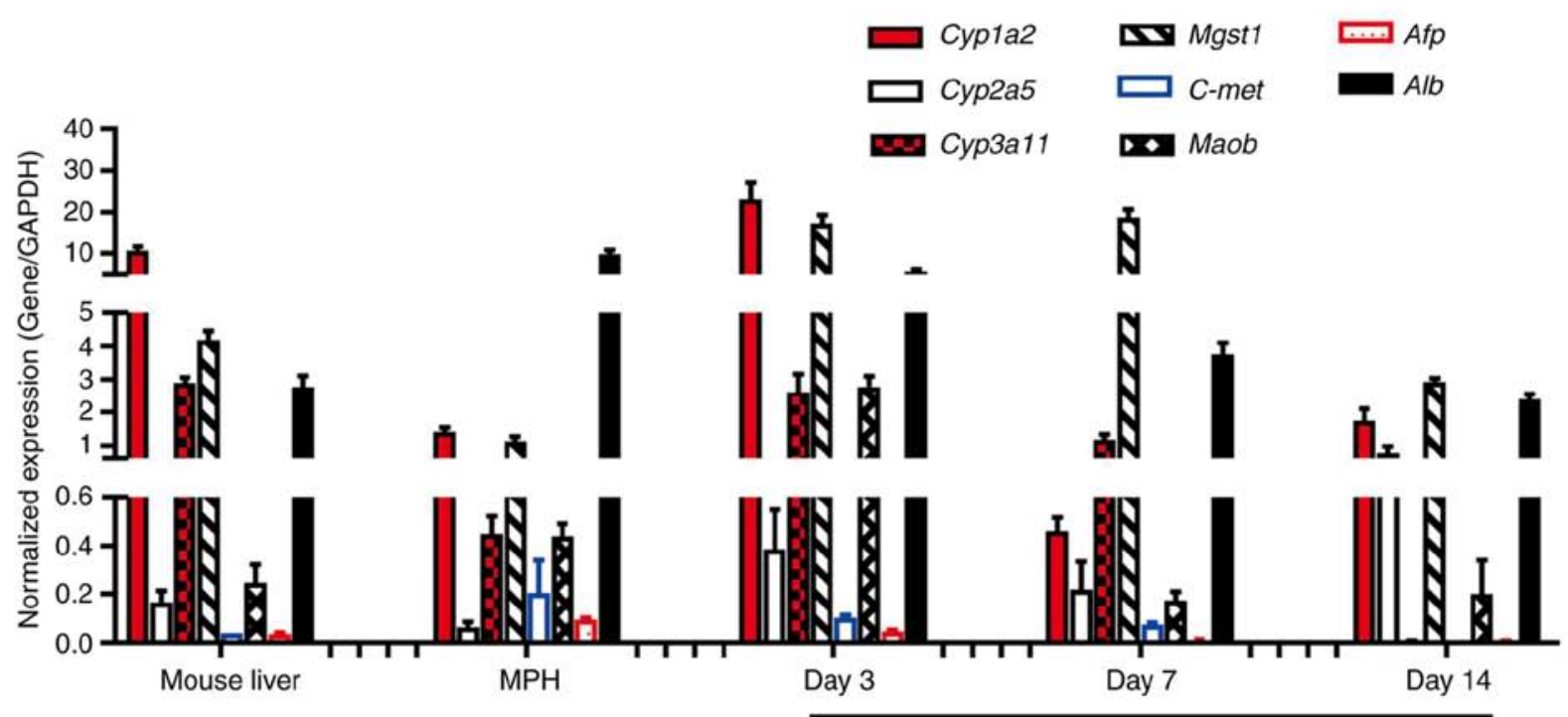

Microsphere

Figure 3. Hepatic functional characterization of 3-dimensional LMTC model. (A) ICG uptake and release assay. (a) The freshly recovered mouse liver sift80 microsphere tissue was incubated with ICG $(1 \mathrm{mg} / \mathrm{ml}$ in $2 \% \mathrm{BCS} / \mathrm{DMEM})$ at $37^{\circ} \mathrm{C}$ for $30 \mathrm{~min}$. ICG uptake was recorded under a bright field microscope. (b) The microsphere tissue was then incubated in $2 \% \mathrm{BCS} / \mathrm{DMEM}$ for an additional $3 \mathrm{~h}$, and the ICG release was recorded under a bright field microscope. Each assay condition was performed in triplicate. Representative results are presented. (B) PAS staining for hepatic glycogen storage. At the indicated time points, the cultured sift 80 microsphere tissue was subjected to PAS staining, and the PAS staining was recorded under a bright field microscope. Each assay condition was performed in triplicate. Representative results are presented. (C) Expression profile of hepatocyte-specific genes in freshly isolated mouse liver tissues, the MPH and the LMTC microsphere tissue cultures at different time points. Total RNA was isolated from the 6-week old C57BL mouse liver, the MPH, and microsphere tissue cultured for 3,7 and 14 days, and subjected to touchdown quantitative polymerase chain reaction analysis to detect the expression of hepatic genes. All samples were normalized with respective GAPDH expression levels. Each assay condition was performed in triplicate. LMTC, liver microsphere tissue culture; ICG, indocyanine green; DMEM, Dulbecco's modified Eagle's medium; PAS, Periodic acid-Schiff; MPH, mouse primary hepatocytes; Cyp1a2, cytochrome P450 family 1 subfamily Amember; Cyp2a5, cytochrome P450 2A5; Cyp3a11, cytochrome P450 family 3 subfamily A member 4; Mgst1, microsomal glutathione S-transferase 1; C-Met, MET proto-oncogene, receptor tyrosine kinase; Maob, monoamine oxidase B; Afp, $\alpha$ fetoprotein; Alb, albumin. 
A
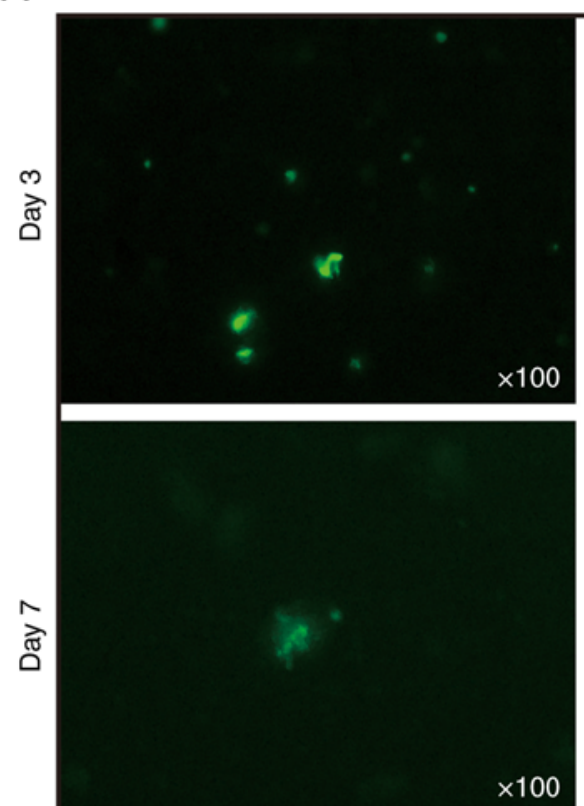

$\times 100$

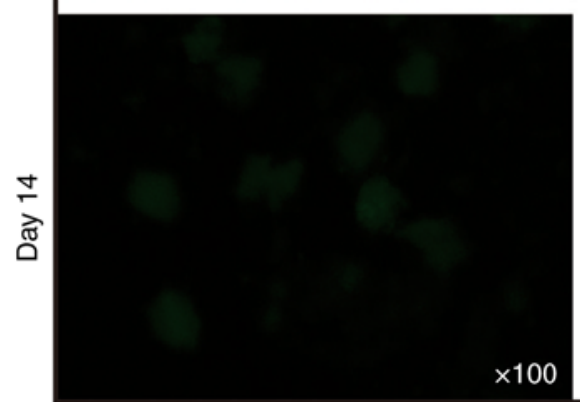

$\mathrm{B}$

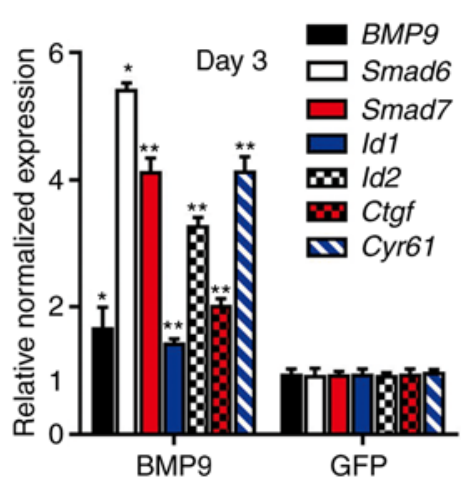

14-days old
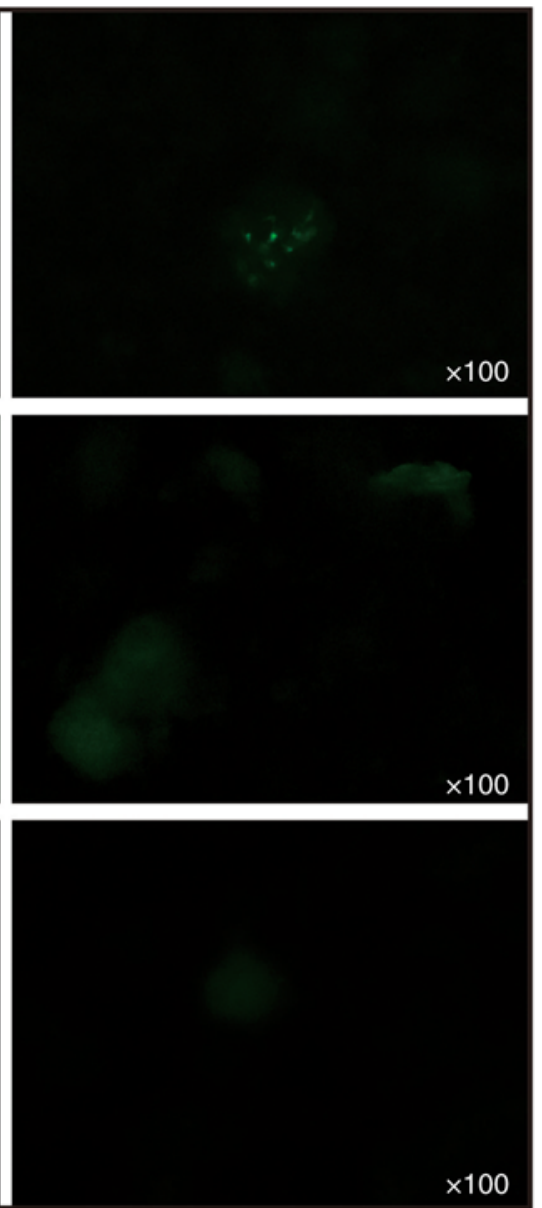

$\times 100$

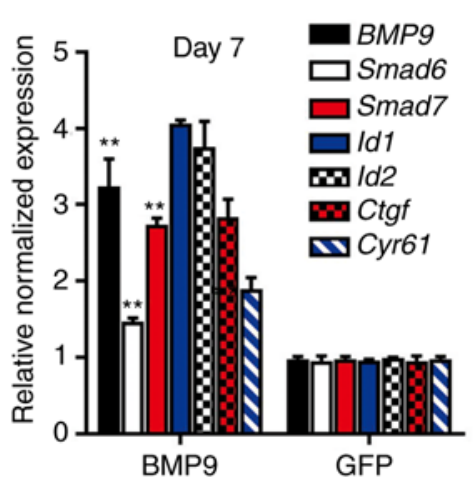

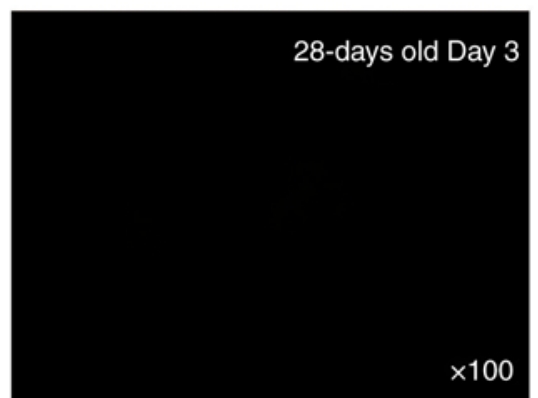
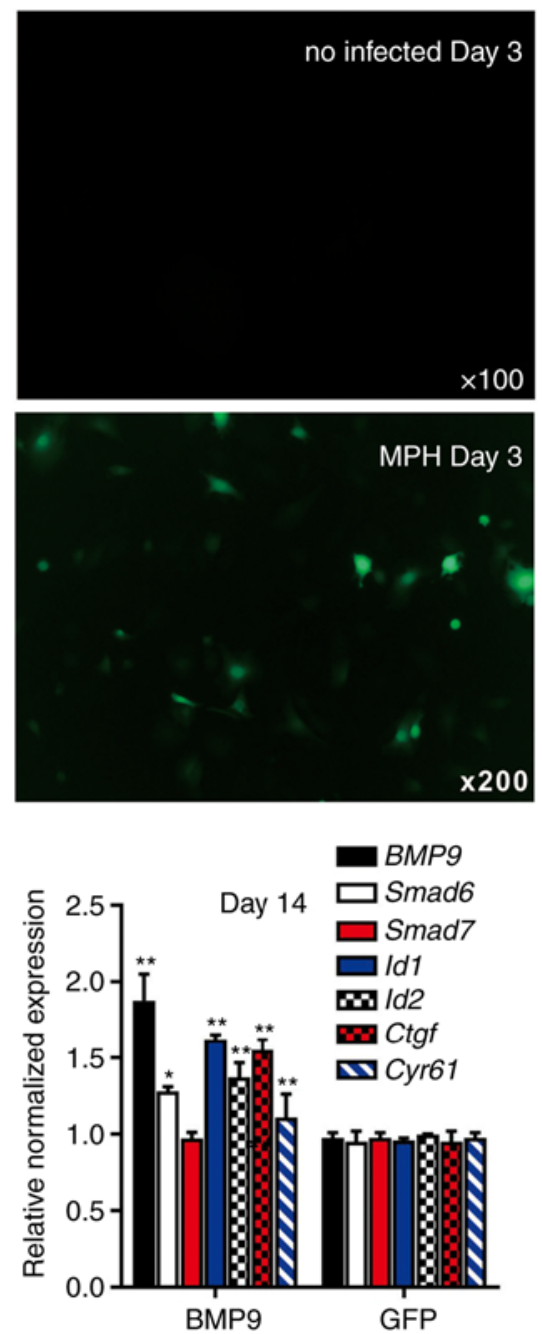

Figure 4. 3-Dimensional liver microsphere tissue culture model for hepatic exogenous investigation. (A) Cultured liver tissue was relatively refractory to Ad-mediated transgene delivery. The microsphere tissue samples were prepared from newborn, 14- and 28-day-old C57BL mouse liver samples, and were infected with the same titer of Ad-GFP. The GFP signal was recorded at 3,7 and 14 days after infection. The MPH were also infected with Ad-GFP as a control, and the GFP signal at day 14 is presented. (B) Stimulation of the sift80 tissue microspheres with BMP9-conditioned medium to examine cell signaling and TqPCR analysis. Total RNA was isolated from the sift 80 tissue microspheres treated with BMP9 or GFP conditioned medium at the indicated time points, and subjected to TqPCR analysis of BMP9 downstream target genes. All samples were normalized with respective $G A P D H$ expression levels. ${ }^{*} \mathrm{P}<0.05$ and ${ }^{* * *} \mathrm{P}<0.01$ vs. GFP groups. Each assay condition was done in triplicate. Ad, adenovirus; GFP, green fluorescent protein; MPH, mouse primary hepatocytes; BMP9, bone morphogenic protein 9; TqPCR, touchdown quantitative polymerase chain reaction analysis; Id1, inhibitor of DNA binding 1, HLH protein; Id2, inhibitor of DNA binding 2; Ctgf, connective tissue growth factor; Cyr61, cellular communication network factor 1.

azithromycin at $125 \mathrm{nM}$ (Fig. 5A-b) and paracetamol at $100 \mu \mathrm{M}$ (Fig. 5A-c).

The effects of the 3 drugs on ICG uptake in the MPH and the freshly prepared sift 80 microspheres were analyzed. When subconfluent MPH cells were treated with levofloxacin (5 $\mu \mathrm{M})$, azithromycin $(125 \mathrm{nM})$, paracetamol $(100 \mu \mathrm{M})$ or DMSO control, the ICG uptake was remarkably inhibited by all 3 drugs at both $24 \mathrm{~h}$ and $72 \mathrm{~h}$, compared with that of the DMSO control group (Fig. 5B-a). However, when the sift80 microsphere tissue was treated with levofloxacin $(5 \mu \mathrm{M})$, azithromycin $(125 \mathrm{nM})$, paracetamol $(100 \mu \mathrm{M})$ or DMSO control, the ICG uptake was not significantly inhibited by the 3 drugs at $24 \mathrm{~h}$, but was markedly inhibited at $72 \mathrm{~h}$, compared with the DMSO control group (Fig. 5B-b). Therefore, these 
A a
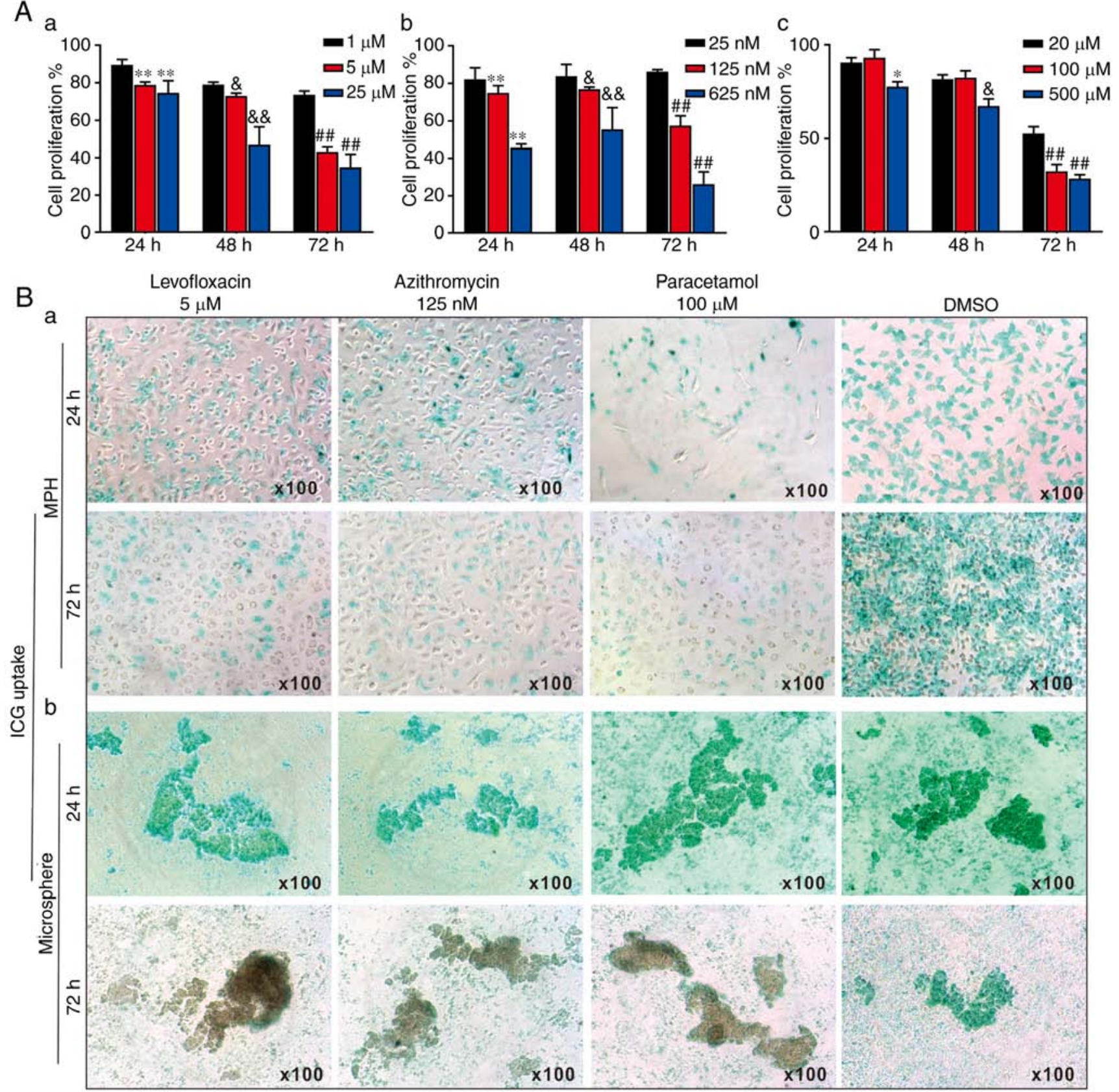

Figure 5. 3-Dimensional liver microsphere tissue culture model for assessing the hepatotoxicity of liver-injury drugs. (A) The effect of 3 liver injury-inducing drugs on hepatic cell proliferation. Subconfluent MPH were seeded in 96-well plates and treated with (a) levofloxacin, (b) azithromycin, (c) paracetamol, or DMSO at the indicated concentrations. At 24, 48 and $72 \mathrm{~h}$ post-treatment, WST-1 reagent was added to the plates and incubated for $1 \mathrm{~h}$ prior to absorbance measurement. (a) ${ }^{* *} \mathrm{P}<0.01$ vs. $1 \mu \mathrm{M}$ at $24 \mathrm{~h}$; ${ }^{\&} \mathrm{P}<0.05$ and ${ }^{\&} \& \mathrm{P}<0.01$ vs. $1 \mu \mathrm{M}$ at $48 \mathrm{~h} ;{ }^{\# \#} \mathrm{P}<0.01$ vs. $1 \mu \mathrm{M}$ at $72 \mathrm{~h}$. (b) ${ }^{* *} \mathrm{P}<0.01$ vs. $25 \mathrm{nM}$ at $24 \mathrm{~h} ;{ }^{\&} \mathrm{P}<0.05$ and ${ }^{\& \&} \mathrm{P}<0.01$ vs. $25 \mathrm{nM}$ at $48 \mathrm{~h} ;{ }^{\# \#} \mathrm{P}<0.01$ vs. $25 \mathrm{nM}$ at $72 \mathrm{~h}$. (c) ${ }^{*} \mathrm{P}<0.05$ vs. $20 \mu \mathrm{M}$ at $24 \mathrm{~h} ;{ }^{\&} \mathrm{P}<0.05$ vs. $20 \mu \mathrm{M}$ at $48 \mathrm{~h}$; ${ }^{\# \#} \mathrm{P}<0.01$ vs. $20 \mu \mathrm{M}$ at $72 \mathrm{~h}$. (B) ICG uptake assay. (a) Subconfluent MPH and (b) sift80 microsphere tissues were treated with levofloxacin $(5 \mu \mathrm{M})$, azithromycin (125 nM), paracetamol (100 $\mu \mathrm{M})$ or DMSO for up to $72 \mathrm{~h}$. The cells and microsphere tissue were incubated with ICG $\left(1 \mathrm{mg} / \mathrm{ml}\right.$ in $2 \%$ BCS/DMEM) at $37^{\circ} \mathrm{C}$ for 30 min, and then the ICG-DMEM was changed to complete DMEM at 24 and $72 \mathrm{~h}$. ICG uptake was recorded under a bright field microscope. Each assay condition was performed in triplicate. Representative images are presented. ICG, indocyanine green; MPH, mouse primary hepatocytes; DMEM, Dulbecco's modified Eagle's medium.

results demonstrate that the mouse liver microsphere tissue culture model may be used as an effective in vitro surrogate system to assess the hepatic functional abnormality caused by hepatotoxic drugs.

Whether the LMTC model was able to predict the hepatotoxicity that was closely correlated with the hepatotoxic effects obtained from in vivo animal studies was also examined. The mice were treated with the levofloxacin, azithromycin, paracetamol or DMSO control, and mouse liver tissue was collected at $24 \mathrm{~h}$ or $72 \mathrm{~h}$ after treatment. Concomitantly, the subconfluent MPH and freshly-prepared sift80 microsphere samples were treated with levofloxacin, azithromycin, paracetamol or DMSO. Total RNA was isolated from the drug-treated mouse liver tissues, the MPH and the sift 80 microspheres for quantitative analysis of the expression of a panel of 5 hepatotoxicity-associated genes, including ATP binding cassette subfamily B member 11 (Abcb11), cytochrome P450 family 2 subfamily E member 1 
A
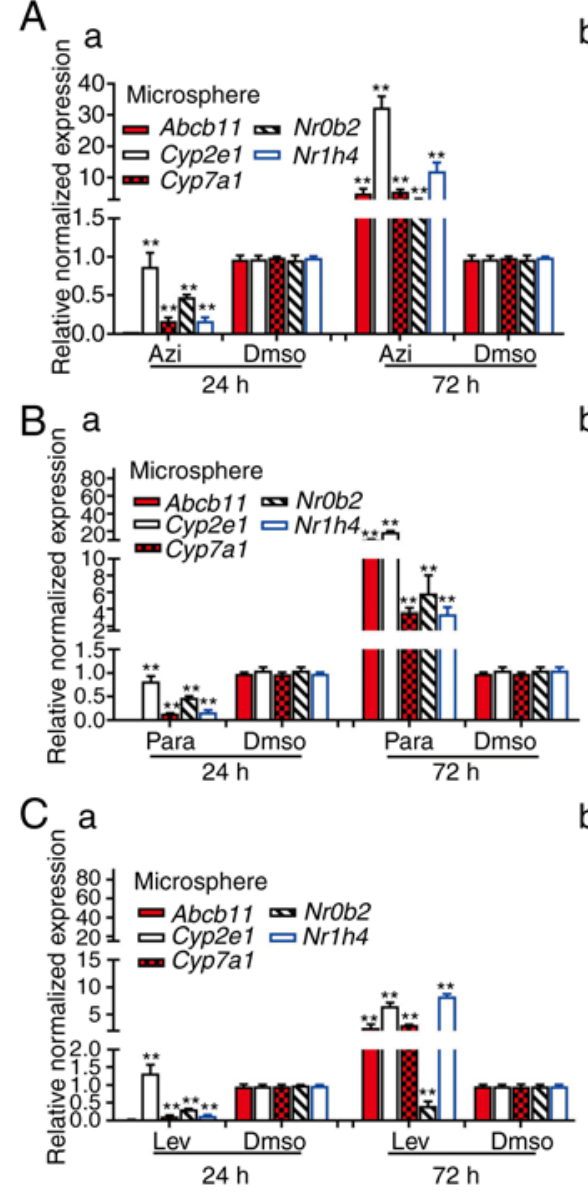
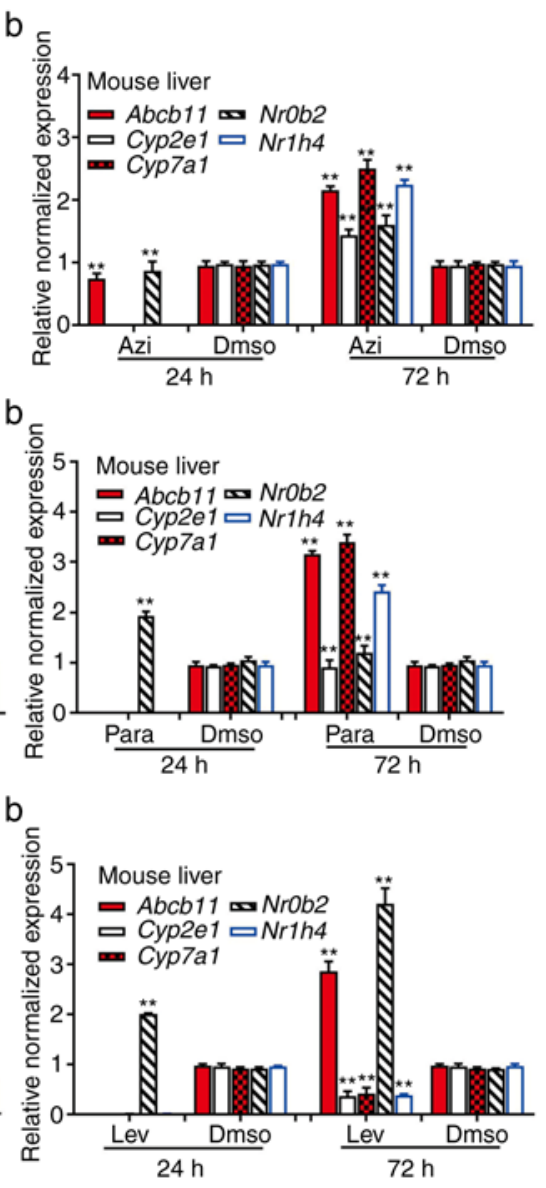
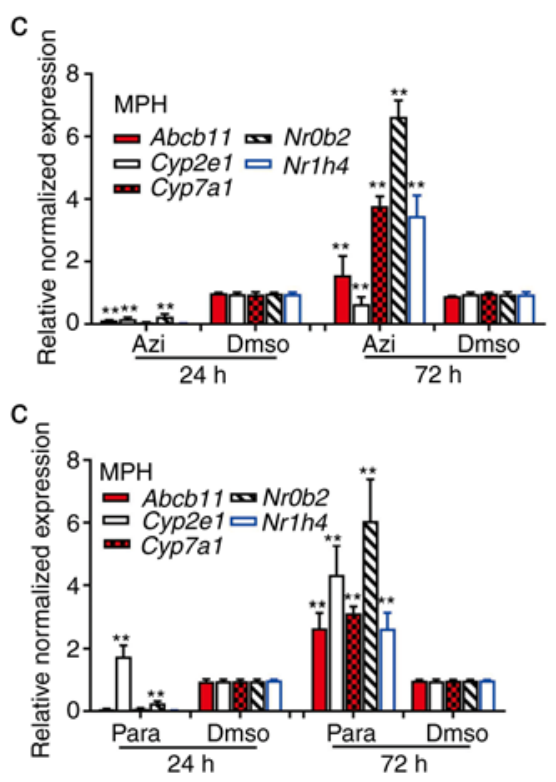

C

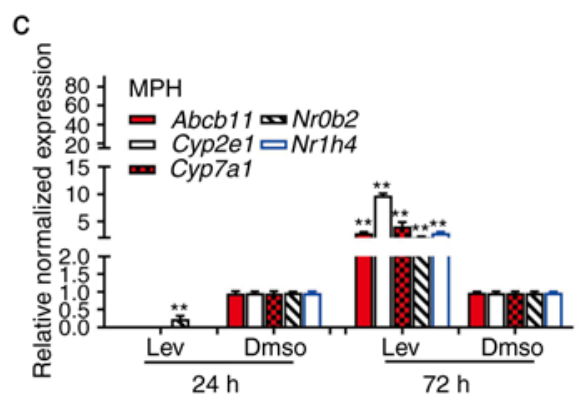

Figure 6. Quantitative analysis of the effects of liver injury-inducing drugs on hepatotoxicity-associated genes. The 4 week-old C57BL/6 male mice (n=5/group) were injected intraperitoneally daily with azithromycin $(12 \mathrm{mg} / \mathrm{kg})$, paracetamol (10 mg/kg), levofloxacin (10 mg/kg) or DMSO for $24 \mathrm{or} 72 \mathrm{~h}$. Concomitantly, subconfluent MPH and freshly isolated sift 80 microsphere tissues were treated with azithromycin $(125 \mathrm{nM})$, paracetamol $(100 \mu \mathrm{M})$, levofloxacin $(5 \mu \mathrm{M})$ or DMSO for 24 or $72 \mathrm{~h}$. Total RNA was isolated from (a) the microsphere tissue, (b) mouse liver tissues and (c) the MPH treated with (A) azithromycin, (B) paracetamol and (C) levofloxacin, and subjected to touchdown quantitative polymerase chain reaction analysis of 5 hepatotoxicity-associated genes. All samples were normalized to respective $G A P D H$ expression levels. Each assay condition was performed in triplicate. ${ }^{* *} \mathrm{P}<0.01$ vs. DMSO group. MPH, mouse primary hepatocytes.

(Cyp2e1), cytochrome P450 family 7 subfamily Amember 1, nuclear receptor subfamily 0 group B member $2(\mathrm{NrOb2})$ and nuclear receptor subfamily 1 group $\mathrm{H}$ member 4 (74-76). In the levofloxacin-treated mouse liver tissue, MPH and sift 80 microsphere tissue groups, while the majority of the hepatotoxicity-associated genes (with the exception of $\mathrm{NrOb} 2$ in the mouse liver group) were not significantly upregulated at $24 \mathrm{~h}$ post treatment, 2/5 genes ( $A b c b 11$ and $\mathrm{NrOb2}$ ) in the mouse liver group, all 5 genes in the MPH group, and 4/5 genes in the sift 80 microsphere tissue group were significantly upregulated at $72 \mathrm{~h}$ after treatment (Fig. 6A). In the azithromycin treatment groups, while all 5 genes were repressed at $24 \mathrm{~h}$, all 5 genes were highly upregulated in all three groups (with the exception of Cyp2el in the MPH group) at $72 \mathrm{~h}$ after treatment (Fig. 6B). Similar results were observed in the paracetamol treatment groups, and all 5 genes were highly upregulated in all three groups (with the exception of Cyp2el in the mouse liver group) at $72 \mathrm{~h}$ after treatment (Fig. 6C). Notably, for the 3 drugs examined, the magnitudes of gene expression upregulation were increased in the sift 80 microsphere tissue groups compared with that in the mouse liver groups at the $72 \mathrm{~h}$ treatment time point, suggesting that the LMTC model may be more sensitive in predicting drug-associated hepatotoxicity.

\section{Discussion}

In the present study, a simple yet effective 3D microsphere culture system of a mouse liver was successfully developed. By freshly preparing the perfused mouse liver tissue with an 80-mesh sift strainer, it was demonstrated that, under the optimal culture condition of $2 \%$ BCS/DMEM, the microspheres remained viable with marked PCNA and c-Myc expression, and exhibited normal hepatic functions, including ICG uptake/release and glycogen synthesis/storage, for up to 2 weeks. However, morphological analysis of cells after 2 weeks of culture revealed tissue degradation and observation of tissue debris, together with diminished hepatic function and gene expression, indicating that the viability of the microspheres may be limited to $<2$ weeks. It was also demonstrated that the cultured microspheres exhibited a similar expression profile of hepatocyte-specific genes to that of the freshly isolated mouse liver tissue. While the microspheres exhibited limited 
intrinsic proliferative potential for transgene expression, it was demonstrated that the microspheres were responsive to BMP9 stimulation, and numerous downstream target genes of BMP9 signaling were effectively upregulated. Furthermore, using 3 commonly-used drugs, levofloxacin, azithromycin and paracetamol, it was revealed that the 3 drugs effectively inhibited hepatic ICG uptake at $72 \mathrm{~h}$ after treatment and induced increased expression levels of hepatotoxicity-associated genes compared with that of the animals treated with these drugs in vivo, suggesting that the LMTC model may be more sensitive in detecting the expression of hepatotoxicity-associated genes, and therefore more sensitive in predicting drug-associated hepatotoxicity.

The liver serves a critical role in biotransformation and disposition of drugs or xenobiotics. As a result, hepatotoxicity may be caused by a wide range of pharmaceutical agents, natural products, chemicals, environmental pollutants or dietary factors $(21,77)$. In fact, hepatotoxicity or DILI is a major cause for drug withdrawals worldwide (22). Commonly-used techniques to assess DILI effects include in vivo animal models and various in vitro models $(14,21-23)$. While the in vivo animal models may more accurately predict drug hepatotoxicity, they are more costly and time-consuming to perform $(14,23)$. Overall, the development of in vitro liver models to study disease and the prediction of metabolism and drug-induced liver injury in humans remains a challenge (78). Therefore, in vivo models are used for the advanced stages of drug development.

There have been numerous attempts to establish ideal in vitro hepatotoxicity assessment systems, which include the uses of primary hepatocytes or established liver cell lines alone or in co-culture with other cell types in 2D and 3D formats, including liver slices, microsomes, perifusion culture systems, co-culture systems, bioreactors, liver 'organ-on-chip' and/or liver organoids $(1,3,6-10,12,14,16-24)$.

The use of primary hepatocytes alone or in a co-culture format is largely limited by the inefficient recovery of primary cells from liver tissue $(77,79)$, which may be easily overcome by the LMTC microsphere tissue culture system described in the present study. Liver cancer lines and/or immortalized liver cell lines are also used as an alternative to primary hepatocytes in these models, although these cell types may not be able to completely replicate the biological characteristics of primary hepatocytes $(3,10,19,22,24)$. In these system, protein and urea synthesis, glucose metabolism and cytochrome (CYP450) activities were stable over a 2 -week culture period, with maximal activities at the end of the first week in the majority of models $(80,81)$. Nonetheless, the maintenance of functional primary hepatocytes cultures has been difficult, due to dedifferentiation and the consequent loss of hepatic function with limited utility (78).

Compared with the hepatocytes cultured in 2D format, 3D hepatocyte culture, such as the LMTC system described in the present study, should result in improved replication of the morphological structure and growth microenvironment of liver cells $(3,7,10)$, as 3D culture models have been demonstrated to be beneficial for cell viability in other organ systems $(50,82,83)$. In other models, the liver slices were prepared by using a tissue slice with a $10-\mathrm{mm}$ diameter motor-driven tissue-coring tool in cold oxygenated $\left(95 \% \mathrm{O}_{2}\right.$ and $\left.5 \% \mathrm{CO}_{2}\right)(16,18)$. Precision-cut liver slices have been used for the investigation of hepatic metabolism, hepatotoxicity and enzyme induction (8). An advantage of using liver slices is the potential for examining the toxic effects on hepatocytes that are mediated by nonparenchymal cells, as the physiological liver microarchitecture is maintained in cultured slices (8). The liver microsomes were prepared by homogenizing the liver tissue with a Potter glass homogenizer equipped with a Teflon pestle followed by ultracentrifugation $(18,20,84)$. It has been demonstrated that long-term stable primary hepatic 3D spheroid cultures in chemically defined conditions may be used to predict drug-induced hepatotoxicity (85). In future studies, the liver microphysiological systems, also referred to as 'liver-on-a-chip', present the opportunity to explore system/organ level effects without using animal experimentation $(1,3,78)$. However, the complexity of the systems and the requirements of the equipment make the wider application of a number of these techniques difficult across the various fields of liver research. Conversely, the LMTC microsphere tissue culture system described in the present study is simple, effective and biologically relevant in terms of replicating hepatic functions in vitro.

In summary, compared with a number of the aforementioned hepatotoxicity assessment systems, the LMTC model described in the present study was relatively simple and easy to prepare, and yet highly effective and reproducible. This microsphere tissue model system required minimal resources and could be maintained for up to 2 weeks. Therefore, this system may be a valuable tool to assess drug-induced hepatotoxicity and metabolism, and to investigate hepatocyte-based cell signaling mechanisms.

\section{Acknowledgements}

Not applicable.

\section{Funding}

The present study was supported in part by research grants from the 2017 Chongqing Postdoctoral Innovation Talent Support Program (JMF), the China Postdoctoral Research Fund (grant no. 2018M643426 to JMF) and the National Key Research and Development Program of China (grant nos. 2016YFC1000803 and 2011CB707906). TCH was also supported by the Mabel Green Myers Research Endowment Fund and The University of Chicago Orthopaedic Surgery Alumni Fund.

\section{Availability of data and materials}

All data generated or analyzed during this study are included in this published article.

\section{Authors' contributions}

YZ, QP, YG, TY and YC performed the experiments. JF, HW and YL analyzed the data, and contributed to data analysis and experimental materials. JF, TCH, QS and AH conceptualized the study design. JF and TH wrote the manuscript. All authors read and approved the final manuscript. 


\section{Ethics approval and consent to participate}

The use and care of animals in the present study was approved by the Research and Experimental Animal Use Ethics Committee of Chongqing Medical University.

\section{Patient consent for publication}

Not applicable.

\section{Competing interests}

The authors declare that they have no competing interests.

\section{References}

1. Beckwitt CH, Clark AM, Wheeler S, Taylor DL, Stolz DB, Griffith L and Wells A: Liver 'organ on a chip'. Exp Cell Res 363: 15-25, 2018.

2. Si-Tayeb K, Lemaigre FP and Duncan SA: Organogenesis and development of the liver. Dev Cell 82: 175-189,2010.

3. Ware BR and Khetani SR: Engineered liver platforms for different phases of drug development. Trends Biotechnol 35: 172-183, 2017.

4. Thapa BR and Walia A: Liver function tests and their interpretation. Indian J Pediatr 74: 663-671, 2007.

5. Kaplowitz N: Idiosyncratic drug hepatotoxicity. Nat Rev Drug Discov 4: 489-499, 2005.

6. Jaeschke H, Gores GJ, Cederbaum AI, Hinson JA, Pessayre D and Lemasters JJ: Mechanisms of hepatotoxicity. Toxicol Sci 65 166-176, 2002.

7. Godoy P, Hewitt NJ, Albrecht U, Andersen ME, Ansari N, Bhattacharya S, Bode JG, Bolleyn J, Borner C, Böttger J, et al: Recent advances in $2 \mathrm{D}$ and $3 \mathrm{D}$ in vitro systems using primary hepatocytes, alternative hepatocyte sources and non-parenchymal liver cells and their use in investigating mechanisms of hepatotoxicity, cell signaling and ADME. Arch Toxicol 87: 1315-1530, 2013

8. Gebhardt R, Hengstler JG, Müller D, Glöckner R, Buenning P, Laube B, Schmelzer E, Ullrich M, Utesch D, Hewitt N, et al: New hepatocyte in vitro systems for drug metabolism: metabolic capacity and recommendations for application in basic research and drug development, standard operation procedures. Drug Metab Rev 35: 145-213, 2003.

9. Bhushan A, Senutovitch N, Bale SS, McCarty WJ, Hegde M, Jindal R, Golberg I, Berk Usta O, Yarmush ML, Vernetti L, et al: Towards a three-dimensional microfluidic liver platform for predicting drug efficacy and toxicity in humans. Stem Cell Res Ther 4 (Suppl 1) S16, 2013.

10. Soldatow VY, Lecluyse EL, Griffith LG and Rusyn I: In vitro models for liver toxicity testing. Toxicol Res (Camb) 2: 23-39, 2013.

11. Pandit A, Sachdeva T and Bafna P: Drug-induced hepatotoxicity: A review. J Appl Pharm Sci 2: 233-243, 2012.

12. Groneberg DA, Grosse-Siestrup C and Fischer A: In vitro models to study hepatotoxicity. Toxicol Pathol 30: 394-399, 2002.

13. Olson H, Betton G, Robinson D, Thomas K, Monro A, Kolaja G, Lilly P, Sanders J, Sipes G, Bracken W, et al: Concordance of the toxicity of pharmaceuticals in humans and in animals. Regul Toxicol Pharmacol 32: 56-67, 2000.

14. Maes M, Vinken $M$ and Jaeschke H: Experimental models of hepatotoxicity related to acute liver failure. Toxicol Appl Pharmacol 290: 86-97, 2016.

15. Clark M and Steger-Hartmann T: A big data approach to the concordance of the toxicity of pharmaceuticals in animals and humans. Regul Toxicol Pharmacol 96: 94-105, 2018.

16. Granhall C, Floby E, Nordmark A, Orzechowski A, Thorne A, Tybring G and Sohlenius-Sternbeck AK: Characterization of testosterone metabolism and 7-hydroxycoumarin conjugation by rat and human liver slices after storage in liquid nitrogen for $1 \mathrm{~h}$ up to 6 months. Xenobiotica 32: 985-996, 2002.

17. Omura T and Sato R: The carbon monoxide-binding pigment of liver microsomes. I. Evidence for its hemoprotein nature. J Biol Chem 239: 2370-2378, 1964.
18. Houston JB and Carlile DJ: Prediction of hepatic clearance from microsomes, hepatocytes, and liver slices. Drug Metab Rev 29: 891-922, 1997.

19. Bi Y, He Y, Huang J, Su Y, Zhu GH, Wang Y, Qiao M, Zhang BQ, Zhang H, Wang Z, et al: Functional characteristics of reversibly immortalized hepatic progenitor cells derived from mouse embryonic liver. Cell Physiol Biochem 34: 1318-1338, 2014.

20. Cogger VC, O'Reilly JN, Warren A and Le Couteur DG: A standardized method for the analysis of liver sinusoidal endothelial cells and their fenestrations by scanning electron microscopy. J Vis Exp 98: e52698, 2015.

21. Bale SS, Moore L, Yarmush M and Jindal R: Emerging in vitro liver technologies for drug metabolism and inter-organ interactions. Tissue Eng Part B Rev 22: 383-394, 2016.

22. Bale SS, Vernetti L, Senutovitch N, Jindal R, Hegde M, Gough A, McCarty WJ, Bakan A, Bhushan A, Shun TY, et al: In vitro platforms for evaluating liver toxicity. Exp Biol Med (Maywood) 239: 1180-1191, 2014.

23. Bhakuni GS, Bedi O, Bariwal J, Deshmukh R and Kumar P: Animal models of hepatotoxicity. Inflamm Res 65: 13-24, 2016.

24. May JE, Xu J, Morse HR, Avent ND and Donaldson C: Toxicity testing: The search for an in vitro alternative to animal testing. $\mathrm{Br}$ J Biomed Sci 66: 160-165, 2009.

25. Seglen PO: Preparation of isolated rat liver cells. Methods Cell Biol 13: 29-83, 1976.

26. Bi Y, Gong M, Zhang X, Zhang X, Jiang W, Zhang Y, Chen J, Liu Y, He TC and Li T: Pre-activation of retinoid signaling facilitates neuronal differentiation of mesenchymal stem cells. Dev Growth Differ 52: 419-431, 2010.

27. Bi Y, Huang J, He Y, Zhu GH, Su Y, He BC, Luo J, Wang Y, Kang Q, Luo Q, et al: Wnt antagonist SFRP3 inhibits the differentiation of mouse hepatic progenitor cells. J Cell Biochem 108: 295-303, 2009.

28. Huang J, Bi Y, Zhu GH, He Y, Su Y, He BC, Wang Y, Kang Q, Chen L, Zuo GW, et al: Retinoic acid signalling induces the differentiation of mouse fetal liver-derived hepatic progenitor cells. Liver Int 29: 1569-1581, 2009.

29. Wang X, Cui J, Zhang BQ, Zhang H, Bi Y, Kang Q, Wang N, Bie P, Yang Z, Wang H, et al: Decellularized liver scaffolds effectively support the proliferation and differentiation of mouse fetal hepatic progenitors. J Biomed Mater Res A 102: 1017-1025, 2014.

30. Fan J, Wei Q, Liao J, Zou Y, Song D, Xiong D, Ma C, Hu X, Qu X, Chen L, et al: Noncanonical Wnt signaling plays an important role in modulating canonical Wnt-regulated stemness, proliferation and terminal differentiation of hepatic progenitors. Oncotarget 8 : 27105-27119, 2017

31. Wu N, Zhang H, Deng F, Li R, Zhang W, Chen X, Wen S, Wang N, Zhang J, Yin L, et al: Overexpression of Ad5 precursor terminal protein accelerates recombinant adenovirus packaging and amplification in HEK-293 packaging cells. Gene Ther 21: 629-637, 2014.

32. National Research Council (US) Committee for the Update of the Guide for the Care and Use of Laboratory Animals: Guide for the Care and Use of Laboratory Animals. National Academies Press (US), Washington, DC, pp963-965, 2011.

33. Cabral F, Miller CM, Kudrna KM, Hass BE, Daubendiek JG, Kellar BM and Harris EN: Purification of hepatocytes and sinusoidal endothelial cells from mouse liver perfusion. J Vis Exp: Feb 12, 2018 (Epub ahead of print). doi: 10.3791/56993.

34. Liu J, Huang X, Werner M, Broering R, Yang D and Lu M: Advanced method for isolation of mouse hepatocytes, liver sinusoidal endothelial cells, and kupffer cells. Methods Mol Biol 1540: 249-258, 2017.

35. Choi WM, Eun HS, Lee YS, Kim SJ, Kim MH, Lee JH, Shim YR, Kim HH, Kim YE, Yi HS and Jeong WI: Experimental applications of in situ liver perfusion machinery for the study of liver disease. Mol Cells 42: 45-55, 2019.

36. Zelepukin IV, Yaremenko AV, Petersen EV, Deyev SM, Cherkasov VR, Nikitin PI and Nikitin MP: Magnetometry based method for investigation of nanoparticle clearance from circulation in a liver perfusion model. Nanotechnology 30: 105101, 2019.

37. Mederacke I, Dapito DH, Affo S, Uchinami H and Schwabe RF: High-yield and high-purity isolation of hepatic stellate cells from normal and fibrotic mouse livers. Nat Protoc 102: 305-315, 2015.

38. He TC, Zhou S, da Costa LT, Yu J, Kinzler KW and Vogelstein B: A simplified system for generating recombinant adenoviruses. Proc Natl Acad Sci USA 955: 2509-2514, 1998.

39. Luo J, Deng ZL, Luo X, Tang N, Song WX, Chen J, Sharff KA, Luu HH, Haydon RC, Kinzler KW, et al: A protocol for rapid generation of recombinant adenoviruses using the AdEasy system. Nat Protoc 2: 1236-1247, 2007. 
40. Lee CS, Bishop ES, Zhang R, Yu X, Farina EM, Yan S, Zhao C, Zheng Z, Shu Y, Wu X, et al: Adenovirus-mediated gene delivery: Potential applications for gene and cell-based therapies in the new era of personalized medicine. Genes Dis 4: 43-63, 2017.

41. Cheng H, Jiang W, Phillips FM, Haydon RC, Peng Y, Zhou L, Luu HH, An N, Breyer B, Vanichakarn P, et al: Osteogenic activity of the fourteen types of human bone morphogenetic proteins (BMPs). J Bone Joint Surg Am 85: 1544-1552, 2003

42. Kang Q, Song WX, Luo Q, Tang N, Luo J, Luo X, Chen J, Bi Y, He BC, Park JK, et al: A comprehensive analysis of the dual roles of BMPs in regulating adipogenic and osteogenic differentiation of mesenchymal progenitor cells. Stem Cells Dev 18: 545-559, 2009.

43. Kang Q, Sun MH, Cheng H, Peng Y, Montag AG, Deyrup AT, Jiang W, Luu HH, Luo J, Szatkowski JP, et al: Characterization of the distinct orthotopic bone-forming activity of 14 BMPs using recombinant adenovirus-mediated gene delivery. Gene Ther 11: 1312-1320, 2004.

44. Li R, Zhang W, Cui J, Shui W, Yin L, Wang Y, Zhang H, Wang N, Wu N, Nan G, et al: Targeting BMP9-promoted human osteosarcoma growth by inactivation of notch signaling. Curr Cancer Drug Targets 14: 274-285, 2014.

45. Li R, Yan Z, Ye J, Huang H, Wang Z, Wei Q, Wang J, Zhao L, Lu S, Wang X, et al: The prodomain-containing BMP9 produced from a stable line effectively regulates the differentiation of mesenchymal stem cells. Int J Med Sci 13: 8-18, 2016

46. Zhao C, Wu N, Deng F, Zhang H, Wang N, Zhang W, Chen X, Wen S, Zhang J, Yin L, et al: Adenovirus-mediated gene transfer in mesenchymal stem cells can be significantly enhanced by the cationic polymer polybrene. PLoS One 9: e92908, 2014

47. Kong Y, Zhang H, Chen X, Zhang W, Zhao C, Wang N, Wu N, He Y, Nan G, Zhang H, et al: Destabilization of heterologous proteins mediated by the GSK3beta phosphorylation domain of the $\beta$-catenin protein. Cell Physiol Biochem 32: 1187-1199, 2013

48. Zhao C, Zeng Z, Qazvini NT, Xu X, Zhang R, Yan S, Shu Y, Zhu Y, Duan C, Bishop E, et al: Thermoresponsive citrate-based graphene oxide scaffold enhances bone regeneration from BMP9-stimulated adipose-derived mesenchymal stem cells. ACS Biomater Sci Eng 4: 2943-2955, 2018.

49. Gao Y, Huang E, Zhang H, Wang J, Wu N, Chen X, Wang N, Wen S, Nan G, Deng F, et al: Crosstalk between Wnt/beta-catenin and estrogen receptor signaling synergistically promotes osteogenic differentiation of mesenchymal progenitor cells. PLoS One 8: e82436, 2013.

50. Yan Z, Yin L, Wang Z, Ye J, Zhang Z, Li R, Denduluri SK Wang J, Wei Q, Zhao L, et al: A novel organ culture model of mouse intervertebral disc tissues. Cells Tissues Organs 201: 38-50, 2016.

51. Liao J, Wei Q, Zou Y, Fan J, Song D, Cui J, Zhang W, Zhu Y, $\mathrm{Ma} \mathrm{C}, \mathrm{Hu} \mathrm{X}$, et al: Notch signaling augments BMP9-induced bone formation by promoting the osteogenesis-angiogenesis coupling process in mesenchymal stem cells (MSCs). Cell Physiol Biochem 41: 1905-1923, 2017.

52. Cui J, Zhang W, Huang E, Wang J, Liao J, Li R, Yu X, Zhao C, Zeng Z, Shu Y, et al: BMP9-induced osteoblastic differentiation requires functional Notch signaling in mesenchymal stem cells. Lab Invest 99: 58-71, 2019.

53. Yu X, Xia Y, Zeng L, Zhang X, Chen L, Yan S, Zhang R, Zhao C, Zeng Z, Shu Y, et al: A blockade of PI3Kgamma signaling effectively mitigates angiotensin II-induced renal injury and fibrosis in a mouse model. Sci Rep 8: 10988, 2018.

54. Zhang Q, Wang J, Deng F, Yan Z, Xia Y, Wang Z, Ye J, Deng Y, Zhang Z, Qiao M, et al: TqPCR: A touchdown qPCR assay with significantly improved detection sensitivity and amplification efficiency of SYBR Green qPCR. PLoS One 10: e0132666, 2016.

55. Livak KJ and Schmittgen TD: Analysis of relative gene expression data using real-time quantitative PCR and the 2(-Delta Delta C(T)) method. Methods 25: 402-408, 2001.

56. Yu X, Liu F, Zeng L, He F, Zhang R, Yan S, Zeng Z, Shu Y, Zhao $\mathrm{C}, \mathrm{Wu} \mathrm{X}$, et al: Niclosamide exhibits potent anticancer activity and synergizes with sorafenib in human renal cell cancer cells. Cell Physiol Biochem 47: 957-971, 2018.

57. Shu Y, Yang C, Ji X, Zhang L, Bi Y, Yang K, Gong M, Liu X, Guo Q, Su Y, et al: Reversibly immortalized human umbilical cord-derived mesenchymal stem cells (UC-MSCs) are responsive to BMP9-induced osteogenic and adipogenic differentiation. J Cell Biochem 119: 8872-8886, 2018.

58. Wang N, Zhang W, Cui J, Zhang H, Chen X, Li R, Wu N, Chen X, Wen S, Zhang J, et al: The piggyBac transposon-mediated expression of SV40 T antigen efficiently immortalizes mouse embryonic fibroblasts (MEFs). PLoS One 9: e97316, 2014.
59. Liao Z, Nan G, Yan Z, Zeng L, Deng Y, Ye J, Zhang Z, Qiao M, Li R, Denduluri S, et al: The anthelmintic drug niclosamide inhibits the proliferative activity of human osteosarcoma cells by targeting multiple signal pathways. Curr Cancer Drug Targets 15: 726-738, 2015.

60. Desmettre T, Devoisselle JM, Soulie-Begu S and Mordon S: Fluorescence properties and metabolic features of indocyanine green (ICG). J Fr Ophtalmol 22: 1003-1016, 1999 (In French).

61. Bi Y, He Y, Huang JY, Xu L, Tang N, He TC and Feng T: Induced maturation of hepatic progenitor cells in vitro. Braz J Med Biol Res 46: 559-566, 2013.

62. Kim DS, Ryu JW, Son MY, Oh JH, Chung KS, Lee S, Lee JJ, Ahn JH, Min JS, Ahn J, et al: A liver-specific gene expression panel predicts the differentiation status of in vitro hepatocyte models. Hepatology 66: 1662-1674, 2017.

63. Nikoozad Z, Ghorbanian MT and Rezaei A: Comparison of the liver function and hepatic specific genes expression in cultured mesenchymal stem cells and hepatocytes. Iran J Basic Med Sci 17: 27-33, 2014.

64. Luu HH, Song WX, Luo X, Manning D, Luo J, Deng ZL, Sharff KA, Montag AG, Haydon RC and He TC: Distinct roles of bone morphogenetic proteins in osteogenic differentiation of mesenchymal stem cells. J Orthop Res 25: 665-677, 2007.

65. Lamplot JD, Qin J, Nan G, Wang J, Liu X, Yin L, Tomal J, Li R, Shui W, Zhang H, et al: BMP9 signaling in stem cell differentiation and osteogenesis. Am J Stem Cells 2: 1-21, 2013.

66. Luther G, Wagner ER, Zhu G, Kang Q, Luo Q, Lamplot J, Bi Y, Luo X, Luo J, Teven C, et al: BMP-9 induced osteogenic differentiation of mesenchymal stem cells: Molecular mechanism and therapeutic potential. Curr Gene Ther 11: 229-240, 2011.

67. Wagner ER, Luther G, Zhu G, Luo Q, Shi Q, Kim SH, Gao JL, Huang E, Gao Y, Yang K, et al: Defective osteogenic differentiation in the development of osteosarcoma. Sarcoma 2011: 325238, 2011.

68. Wang RN, Green J, Wang Z, Deng Y, Qiao M, Peabody M, Zhang Q, Ye J, Yan Z, Denduluri S, et al: Bone Morphogenetic Protein (BMP) signaling in development and human diseases. Genes Dis 1: 87-105, 2014.

69. Zhou L, An N, Jiang W, Haydon R, Cheng H, Zhou Q, Breyer B, Feng $\mathrm{T}$ and $\mathrm{He} \mathrm{TC}$ : Fluorescence-based functional assay for Wnt/beta-catenin signaling activity. Biotechniques 33: 1126-1128, 1130, 1132 passim, 2002.

70. Luo Q, Kang Q, Si W, Jiang W, Park JK, Peng Y, Li X, Luu HH, Luo J, Montag AG, et al: Connective tissue growth factor (CTGF) is regulated by Wnt and bone morphogenetic proteins signaling in osteoblast differentiation of mesenchymal stem cells. J Biol Chem 279: 55958-55968, 2004.

71. Peng Y, Kang Q, Cheng H, Li X, Sun MH, Jiang W, Luu HH, Park JY, Haydon RC and He TC: Transcriptional characterization of bone morphogenetic proteins (BMPs)-mediated osteogenic signaling. J Cell Biochem 90: 1149-1165, 2003.

72. Peng Y, Kang Q, Luo Q, Jiang W, Si W, Liu BA, Luu HH, Park JK, Li X, Luo J, et al: Inhibitor of DNA binding/differentiation helix-loop-helix proteins mediate bone morphogenetic protein-induced osteoblast differentiation of mesenchymal stem cells. J Biol Chem 279: 32941-32949, 2004.

73. Si W, Kang Q, Luu HH, Park JK, Luo Q, Song WX, Jiang W, Luo X, Li X, Yin H, et al: CCN1/Cyr61 is regulated by the canonical Wnt signal and plays an important role in Wnt3A-induced osteoblast differentiation of mesenchymal stem cells. Mol Cell Biol 26: 2955-2964, 2006

74. Ramappa V and Aithal GP: Hepatotoxicity related to anti-tuberculosis drugs: Mechanisms and management. J Clin Exp Hepatol 3: 37-49, 2013.

75. Njoku DB: Drug-induced hepatotoxicity: Metabolic, genetic and immunological basis. Int J Mol Sci 15: 6990-7003, 2014.

76. Perwitasari DA, Atthobari J and Wilffert B: Pharmacogenetics of isoniazid-induced hepatotoxicity. Drug Metab Rev 47: 222-228, 2015.

77. Bale SS, Golberg I, Jindal R, McCarty WJ, Luitje M, Hegde M, Bhushan A, Usta OB and Yarmush ML: Long-term coculture strategies for primary hepatocytes and liver sinusoidal endothelial cells. Tissue Eng Part C Methods 21: 413-422, 2015.

78. Hughes DJ, Kostrzewski T and Sceats EL: Opportunities and challenges in the wider adoption of liver and interconnected microphysiological systems. Exp Biol Med (Maywood) 242: 1593-1604, 2017.

79. Kegel V, Deharde D, Pfeiffer E, Zeilinger K, Seehofer D and Damm G: Protocol for isolation of primary human hepatocytes and corresponding major populations of non-parenchymal liver cells. J Vis Exp e53069, 2016. 
80. Riccalton-Banks L, Liew C, Bhandari R, Fry J and Shakesheff K Long-term culture of functional liver tissue: Three-dimensional coculture of primary hepatocytes and stellate cells. Tissue Eng 9: 401-410, 2003.

81. Rebelo SP, Costa R, Silva MM, Marcelino P, Brito C and Alves PM: Three-dimensional co-culture of human hepatocytes and mesenchymal stem cells: Improved functionality in long-term bioreactor cultures. J Tissue Eng Regen Med 11: 2034-2045, 2017.

82. Chen L, Jiang W, Huang J, He BC, Zuo GW, Zhang W, Luo Q, Shi Q, Zhang BQ, Wagner ER, et al: Insulin-like growth factor 2 (IGF-2) potentiates BMP-9-induced osteogenic differentiation and bone formation. J Bone Miner Res 25: 2447-2459, 2010.

83. Huang E, Zhu G, Jiang W, Yang K, Gao Y, Luo Q, Gao JL, Kim SH, Liu X, Li M, et al: Growth hormone synergizes with BMP9 in osteogenic differentiation by activating the JAK/STAT/IGF1 pathway in murine multilineage cells. J Bone Miner Res 27: $1566-1575,2012$.
84. Khetani SR and Bhatia SN: Microscale culture of human liver cells for drug development. Nat Biotechnol 26: 120-126, 2008.

85. Vorrink SU, Zhou Y, Ingelman-Sundberg M and Lauschke VM: Prediction of drug-induced hepatotoxicity using long-term stable primary hepatic 3D spheroid cultures in chemically defined conditions. Toxicol Sci 163: 655-665, 2018.

This work is licensed under a Creative Commons Attribution-NonCommercial-NoDerivatives 4.0 International (CC BY-NC-ND 4.0) License. 